\title{
15. MINERALOGY AND DIAGENESIS OF SLOPE SEDIMENTS OFFSHORE GUATEMALA AND COSTA RICA, DEEP SEA DRILLING PROJECT LEG 84
}

\author{
Roger Helm, Geologisches Institut, Ruhr-Universität ${ }^{2}$
}

\begin{abstract}
The distribution and composition of minerals in the silt and clay fraction of the fine-grained slope sediments were examined. Special interest was focused on diagenesis. The results are listed as follows. (1) Smectite, andesitic plagioclase, quartz, and low-Mg calcite are the main mineral components of the sediment. Authigenic dolomite was observed in the weathering zones of serpentinites, together with aragonite, as well as in clayey silt. (2) The mineralogy and geochemistry of the sediments is analogous to that of the andesitic rocks of Costa Rica and Guatemala. (3) Unstable components like volcanic glass, amphiboles, and pyroxenes show increasing etching with depth. (4) The diagenetic alteration of opal-A skeletons from etching pits and replacement by opal-CT to replacement by chalcedony as a final stage corresponds to the typical opal diagenesis. (5) Clinoptilolite is the stable zeolite mineral according to mineral stability fields; its neoformation is well documented. (6) The early diagenesis of smectites is shown by an increase of crystallinity with depth. Only the smectites in the oldest sediments (Oligocene and early Eocene) contain nonexpanding illite layers.
\end{abstract}

\section{INTRODUCTION}

The results of Leg 67 suggested a nonaccreting slope offshore Guatemala, a pre-Tertiary igneous or sedimentary basement beneath the slope sediment, and the frequent occurrence of gas hydrates in the slope sediments (von Huene and Aubouin, 1982). Some remaining questions were answered by Leg 84 . The slope consists of a nonaccreting sediment complex that covers a pre-early Eocene ophiolite basement (Fig. 1). Drilling yielded more understanding of gas hydrate formation and stability (Kvenvolden, this volume). An outstanding drilling result was the discovery of a 1- to 3-m-thick layer of gas hydrate at Site 570. An additional site was drilled offshore Costa Rica's Nicoya Peninsula in order to study the basement. However, drilling had to be stopped before the basement was reached because of troubles in the borehole.

Because studies of the lateral and vertical distribution of minerals within the slope sediments already exist (Heinemann and Füchtbauer, 1982; Prasad and Hesse, 1982; Kurnosov et al., 1982), the present investigation focused on the diagenesis and mineralogy of plagioclases, clay minerals, volcanic glass, zeolites, and carbonates recovered during Leg 84 .

\section{METHODS}

Sediment samples were dispersed with a high-frequency stirrer in deionized water, and the sand fraction was separated by sieving. Glass shards and opaline tests were taken from this fraction for electron microscopy and refractive index measurements. To remove flocculating ions, the fraction $<63 \mu \mathrm{m}$ was washed several times using $0.01 \mathrm{~N}$ $\mathrm{NH}_{4} \mathrm{OH}$. The carbonates were not treated with acids in order to avoid destruction of delicate minerals. For the same reason the samples were dried under vacuum at 40 to $60^{\circ} \mathrm{C}$ only. The fractions $<2,2$ to 6.3 , 6.3 to 20 , and 20 to $63 \mu \mathrm{m}$ were collected by Atterberg separation (Müller, 1964).

\footnotetext{
${ }^{1}$ von Huene, R., Aubouin, J., et al., Init. Repts. DSDP, 84: Washington (U.S. Govt. Printing Office).

2 Address: Geologisches Institut, Ruhr-Universităt, Bochum, West Germany.
}

Detailed X-ray diffractograms of all these fractions were recorded from 2 to $65^{\circ}(2 \theta, \mathrm{Cu} \mathrm{K} \alpha)$, using $\mathrm{NaF}$ and quartz as internal standards. A suspension of the $<2-\mu \mathrm{m}$ fraction was allowed to dry on a glass slide for X-ray diffraction (XRD) analyses of air-dried samples. Samples dried at $350^{\circ}$ and $500^{\circ} \mathrm{C}$ as well as glycolated splits were also analyzed.

The distribution of clay minerals in the $\langle 2-\mu \mathrm{m}$ fraction was determined using the Biscaye method (Biscaye, 1965).

Differential thermal analyses and infrared spectroscopy were used as additional diagnostic methods. For infrared spectroscopy $\mathrm{KBr}$ disks composed of a mixture of $450 \mathrm{mg} \mathrm{KBr}$ and $1 \mathrm{mg}$ of the sample were prepared applying a pressure of 10 tons. Electron micoscopy with an energy-dispersive spectrometer (EDAX) was used to study the appearance and composition of newly formed minerals and the surface of siliceous skeletons and glass shards. Total carbonate was determined by the Scheibler method (using $\mathrm{HCl}$ and recording the $\mathrm{CO}_{2}$ pressure) (Müller, 1964). All chemical analyses were calculated on a water and carbonate-free basis. The chemical analyses of the bulk sample were carried out using $\mathrm{X}$-ray fluorescence with the $\mathrm{Li}_{2} \mathrm{~B}_{4} \mathrm{O}_{2} / \mathrm{LiBO}_{2}$ glass disk method. The analyses of the clay fraction and carbonates were made by atomic absorption spectroscopy using $\mathrm{LiBO}_{7}$ disintegration.

Ionic activities and saturation indexes for different minerals were calculated for 20 interstitial waters of Leg 84 using the WATEQ computer program, according to Truesdell and Jones (1973). Downhole variation of ionic activities and saturation indexes of minerals could therefore be established. Pore-water composition values were taken from Leg 67 (Harrison et al., 1982), from pore-water analyses of Leg 84 (J. Lebel, personal communication, 1983), and from the Leg 84 site reports. Although the gas hydrates suggest that organic acids are present, these could not be considered because no data of dissolved organic species in the interstitial water of Leg 84 are available.

\section{Mineral Identification}

Quartz was identified with X-ray diffraction by the main peaks at 24.64 and $28.85^{\circ}(2 \theta, \mathrm{Cu} \mathrm{K} \alpha)$. The plagioclase composition was determined by X-ray diffraction using the (13T) peak (Goodyear and Duffin, 1954). Other methods were not practical, because the (13I) peak was the only one with sufficient intensity.

The compositions of calcite and dolomite were calculated using the (104) d-spacing. The degree of dolomite lattice order was established by the $(015) /(110)$ peak ratio according to Goldsmith and Graf (1958). Additional wet chemical analyses of calcareous sediments were carried out, using atomic absorption spectroscopy.

The distinction between clinoptilolite and heulandite was based on $\mathrm{X}$-ray diffraction after heating the samples overnight to $550^{\circ} \mathrm{C}$. According to Alietti (1972), only the heulandite lattice should be destroyed after this heat treatment.

Opal-A of siliceous skeletons was identified either optically or by the broad X-ray peak between 17 and $30^{\circ}(2 \theta, \mathrm{Cu} \mathrm{K} \alpha)$ that appears as 


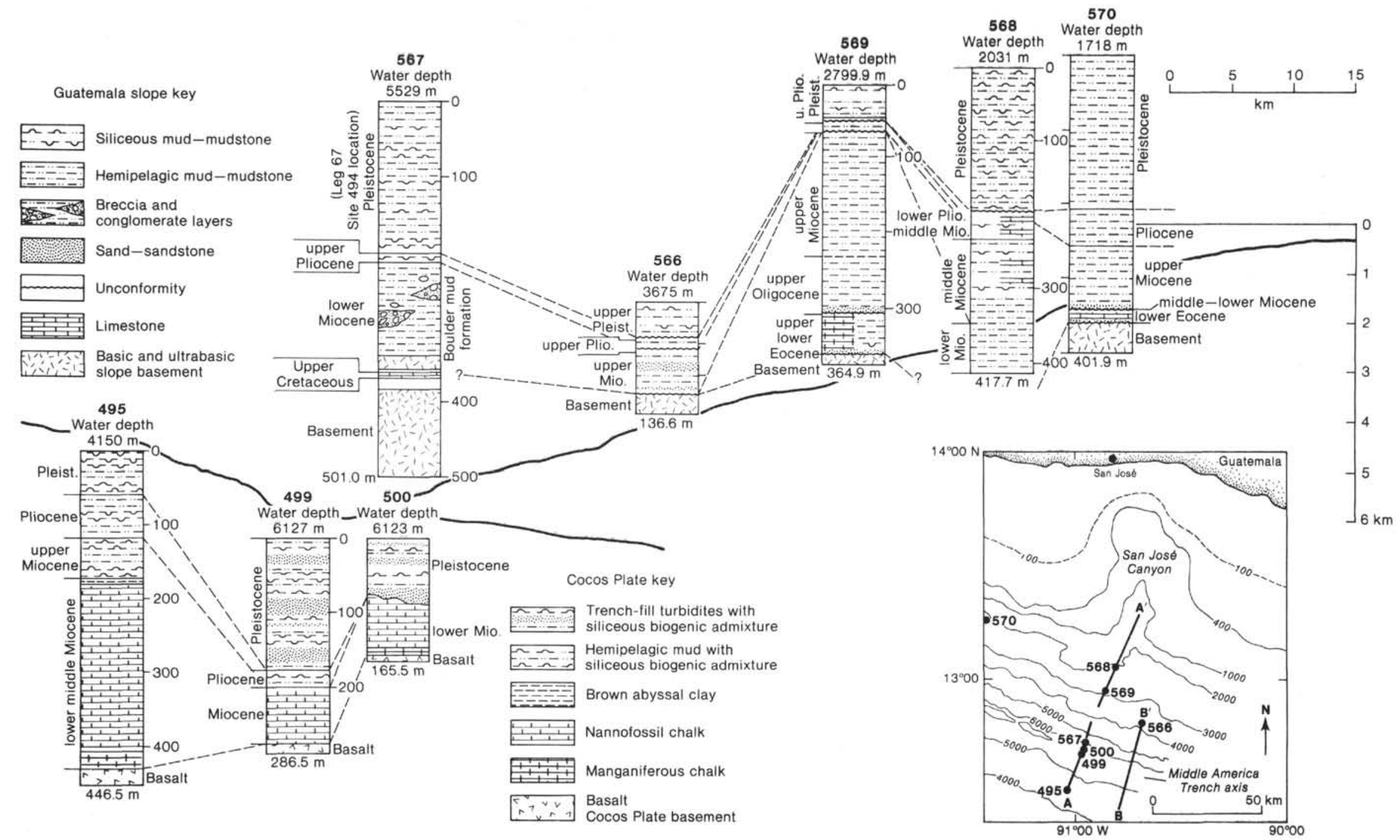

Figure 1. Lithostratigraphic columns of Legs 84 and 67 sites and site locations along the Middle America Trench offshore Guatemala (Aubouin et al., 1982). Site 565, off Costa Rica, is not shown on this map. 
a raised X-ray background in the mentioned $2 \theta$ region. The opal- $\mathrm{A}$ peak, however, is overlain by the broad reflection of volcanic glass with similar X-ray diffraction patterns. In order to investigate the very early stages of diagenesis, the refraction index of opal-A (sponge spicules) was determined using the $\lambda$-T method (Pillar, 1952). Etching and mineral precipitation in siliceous tests were studied using the electron microscope with an additional energy-dispersive spectrometer. The refractive index of glass shards was determined also using the $\lambda$ - $T$ method. For all studies, glass was enriched by centrifuging ash-rich sediments as follows: A bromoform-methanol mixture with the density of rhyolitic or andesitic glass was prepared. From this fluid, the suspended shards were collected with a pipette, while clay and opal-A floated at the surface and plagioclase, quartz, and carbonate grains sank to the bottom.

Because of their low concentrations, it was impossible to distinguish kaolinite from chlorite using the d-spacings of kaolinite $(002)$ and chlorite (004). The percentages of these minerals were calculated from the peak area of the $7-\hat{\mathrm{A}} \mathrm{d}$-spacing, using the Biscaye (1965) method. The percentages of nonexpandable layers in smectites were established using methods recommended by Reynolds and Hower (1970) and Brindley and Brown (1980); partial destruction of the 7-Å peak after heating to $500^{\circ} \mathrm{C}$ was interpreted as indicating the presence of chlorite. In order to investigate the crystallinity of smectites the peak height/width at half height ratio was measured in untreated and glycolated samples as shown in Figure 2. To determine the crystallinity of the 10-A peak that was formed by heat treatment from the smectite 14 - to $15-\AA \hat{\text { p peak}}$, the so-called "10- $\hat{A}$-index" was used. This was established as shown

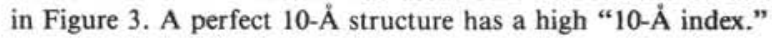

\section{RESULTS}

\section{General Composition}

The predominant slope sediment is a green mud with a maximum of grain size distribution in the clayey silt range (Fig. 4). Second in frequency are sandy silts and sand-silt-clays.

The main constituents in the sediments are acidic volcanic glass and intermediate plagioclase. Quantitative determinations in Leg 67 slope sediments (Heinemann and Füchtbauer, 1982; Kurnosov et al., 1982) show the concentration of these components in the bulk sediment to range from 30 to $80 \%$. Smear-slide data of Leg 84 slope sediments confirm these measurements. The sediment has very low quartz content, which seldom exceeds $10 \%$ (Heinemann and Füchtbauer, 1982).

Other important constituents are calcite and siliceous opal-A. The latter constituent was found as radiolarians, diatoms, sponge spicules, and isolated silicoflagellates. The average amount of opal-A is 10 to $20 \%$. Sediments with higher opal-A content are very rare, according to the Leg 84 site reports. Carbonate mostly occurs as foraminiferal tests, calcareous nannofossils, or unspecified carbonate grains.

Limestones were drilled in the lower sediment sections of Holes 565, 567, 569A, and 570. Dolomite was recovered at Sites 566, 567, and 570. Volcanic glass of rhyolitic composition increases to an amount over $90 \%$ in distinct ash layers. Volcanic glass is a very minor constituent of the slope sediments off Costa Rica (Site 565). The glass contents at the sites off Guatemala are higher, and the greatest occurrence of distinct ash layers was observed at Site 568 . The main clay mineral is smectite.

\section{Clastic Minerals}

Quartz could be identified in almost every sample. Maxima of quartz often correlate positively with maxi-

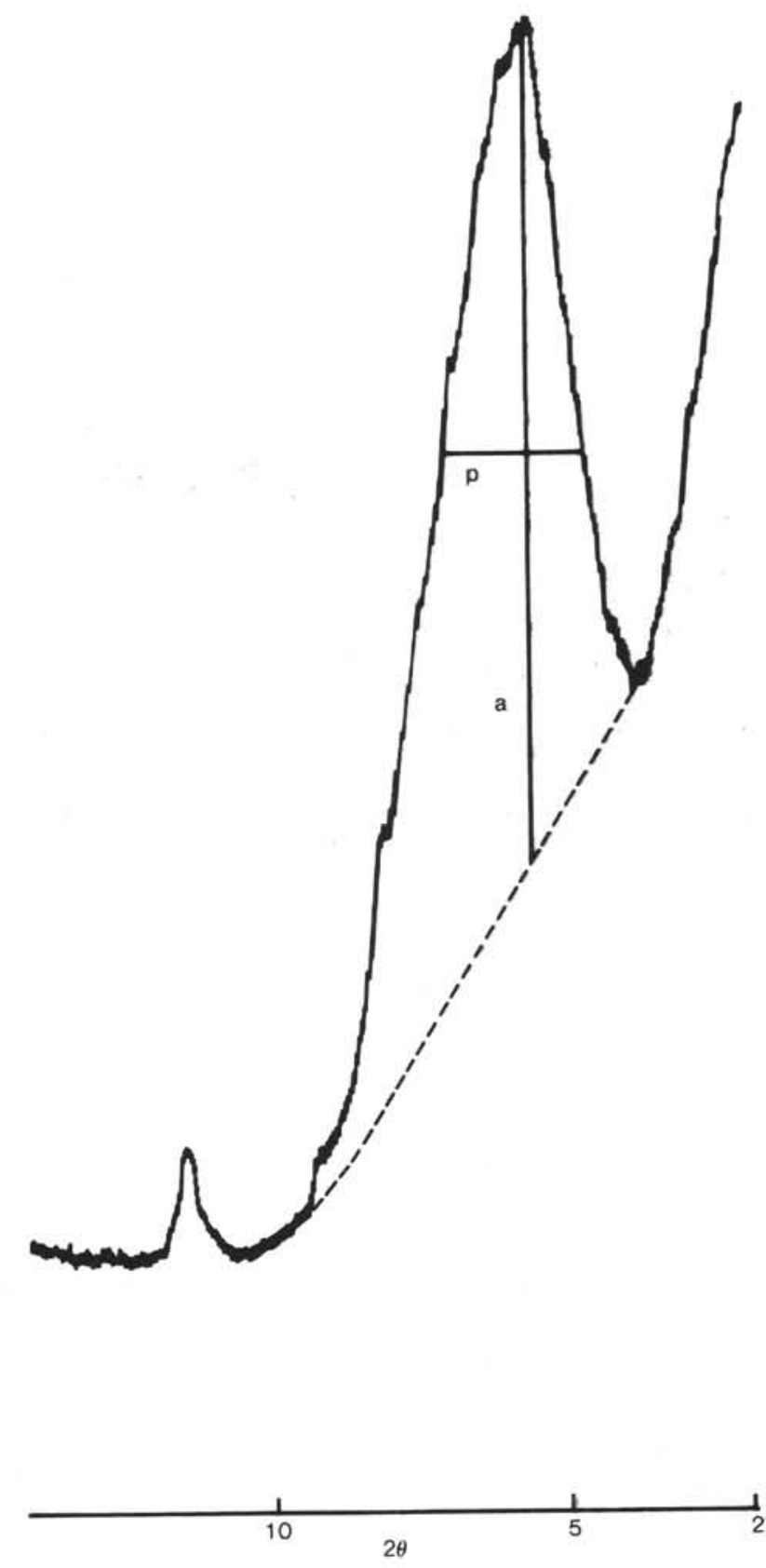

Figure 2. Calculation of peak height/peak width ratio as used in this chapter. The ratio $a / p$ is the peak height/width (at half height) ratio that is used here instead of other measures of crystallinity.

ma of plagioclase and calcite. Quartz occurs even in the clay fractions. Very low $(\sim 2 \%)$ amounts of quartz can be related to distinct ash layers. All interstitial water samples investigated are oversaturated for quartz. No authigenic quartz cement was observed.

Plagioclase and volcanic glass are the main detrital components of the Leg 84 sediments. The slope sediments off Guatemala contain 5 to $50 \%$ plagioclase (Heinemann and Füchtbauer, 1982). Their composition ranges from andesine to oligoclase. Labradorite and albite were only identified where admixtures of ophiolitic detritus were found (Site 567). The highest plagioclase amounts were recognized in the 20 - to $63-\mu \mathrm{m}$ fraction, the lowest in the 


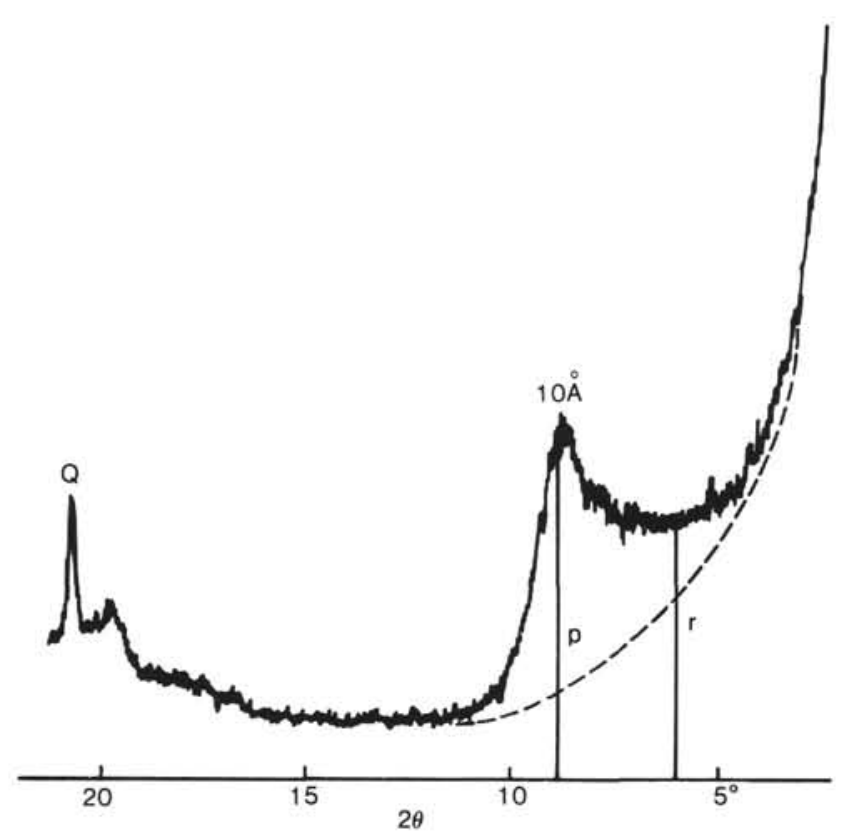

Figure 3. Calculation of the " $10-\AA$ index" used in this paper. " $10-\AA$ index" $=\mathrm{p} / \mathrm{r}$. Q = quartz. Dashed line indicate the X-ray background correction.

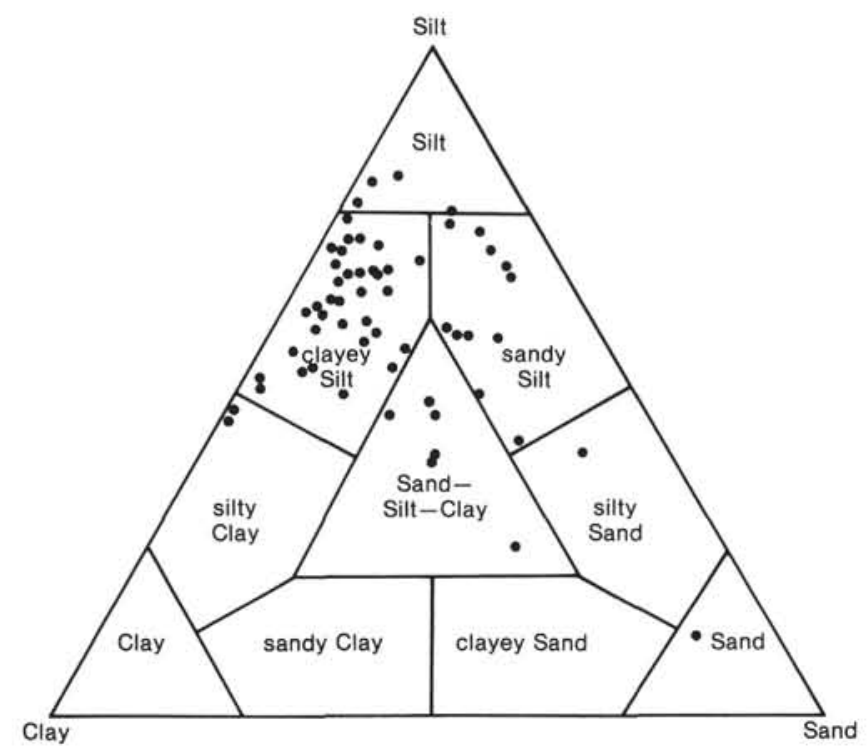

Figure 4. Sediment classification after Shephard (1954) for all sites $565,566,567,568,569$ (including Hole 569A), and 570.

clay fraction. The pore waters are 100 to 10,000 times oversaturated for albite and more or less undersaturated (10-100 times) for anorthite.

However, replacement of plagioclase grains by smectites and calcite can be seen in the consolidated basal sediments of Site 570 .

\section{Carbonates}

In the unconsolidated sediments, calcite occurs as microfossil tests or undefined carbonate detritus, whereas in the $>63-\mu \mathrm{m}$ fraction, calcite macrofossil tests occur. In the consolidated samples, calcite occurs either as a micritic or blocky cement; the latter consists of Fe-calcite in place $(570-37-1,30-32 \mathrm{~cm}$ and $570-38-1,50-52$ $\mathrm{cm})$. Calcite can be identified in all grain size fractions. The samples studied from the sites offshore Guatemala show distinctly higher calcite abundances than those offshore Costa Rica. The $\mathrm{MgCO}_{3}$ content of calcite varies between $\sim 1$ and $6 \%$. However, a few high-Mg calcite occurrences $\left(\mathrm{MgCO}_{3}=10-15 \%\right)$ can be identified in the slope sediments of Holes 569, 569A, and 570, in the coarse as well as in the finer silt fractions.

The Cretaceous limestone drilled in Core 19 at Site 567 contains pelagic foraminifer tests that are filled with clinoptilolite and chalcedony. This limestone as well as the other calcite-bearing samples investigated have relatively high manganese contents (Table 1). Theoretical Sr/ $\mathrm{Ca}$ mole ratios of about 0.004 (Table 1) were calculated for a solution in equilibrium with the investigated recrystallized limestones, according to Wolff and Füchtbauer (1976). The $\mathrm{Sr} / \mathrm{Ca}$ ratios of the actual interstitial fluids in the slope sediments, however, are about 10 times higher (0.01-0.04). The ratio calculated for the sediment at the sediment/water interface is closer $(0.008)$ to the ratios calculated for the calcites investigated.

Calcite is oversaturated 1 to 10 times in most of the interstitial water samples investigated, as established by the WATEQ calculations.

Dolomite was found in a few samples only, which are described as follows: (1) Uncorroded isolated dolomite rhombs are strongly enriched in the 6.3 to $20-\mu \mathrm{m}$ fraction of a Site 570 mud $(570-19-2,76-78 \mathrm{~cm})$ (Plates 2, Fig. 1 and 3, Fig. 4). X-ray analyses indicate 55 mole \% $\mathrm{CaCO}_{3}$ and accordingly a lowered lattice order (Table 1). (2) Dolomitized foraminifers are dispersed in a micritic dolomite (567-5-3, 107-108 cm). The composition is $\mathrm{Ca}_{54} \mathrm{Mg}_{46}$ with a relatively low lattice order (Table 1). (3) Sample $570-27-1,10-12 \mathrm{~cm}$ is a micritic dolomite with plagioclase and quartz clasts. The dolomite is almost stoichiometric $\left(\mathrm{Ca}_{51}\right.$-dolomite) and has a very high crystal lattice order (Table 1). The average size of dolomite rhombs in this dolomicrite is 3 to $10 \mu \mathrm{m}$. (4) In Sample 566-5-3, 83-85 cm serpentinite clasts are dispersed in a dolomicrite rock. Dolomite occurs also as vein fillings in fractured solid serpentinites. Its composition is $\mathrm{Ca}_{53} \mathrm{Mg}_{47}\left(\mathrm{CO}_{3}\right)_{2}$ with a low degree of lattice order (Plate 2, Fig. 3, Table 1).

The analyzed dolomites show the same relationship between $\mathrm{Sr} / \mathrm{Ca}$ ratios in calculated equilibrium solution (Table 1) and interstitial waters as do the calcites. Dolomite in the interstitial waters reaches oversaturations of $1 \times 10^{2}$ to $1 \times 10^{3}$.

Shell fragments of fibrous aragonite were found in the clastic sediments of Site 570. Aragonite was also found in serpentinitic mud as fibrous concretions and in solid serpentinites as vein fillings $(566-5, \mathrm{CC})$.

Calculated $\mathrm{Sr} / \mathrm{Ca}$ ratios in theoretical equilibrium solutions correspond to the values calculated for calcite and dolomite. The calculated oversaturations of interstitial waters are low and do not exceed a factor of five. Sometimes undersaturation is calculated for interstitial water samples squeezed from sediments near to the sediment/water interface. 
Table 1. Chemical, X-ray, and thin-section data of carbonate samples.

\begin{tabular}{|c|c|c|c|c|c|c|c|c|}
\hline \multirow[b]{2}{*}{ Mineral } & \multirow{2}{*}{$\begin{array}{c}\text { Sample } \\
\text { (interval in } \mathrm{cm} \text { ) }\end{array}$} & \multirow{2}{*}{$\begin{array}{l}\text { Mineral } \\
\text { compo- } \\
\text { sition }\end{array}$} & \multirow{2}{*}{$\begin{array}{l}\text { Dolomite } \\
\text { lattice } \\
\text { order }\end{array}$} & \multirow{2}{*}{$\underset{(\mathrm{ppm})}{\mathrm{Sr}}$} & \multirow{2}{*}{$\begin{array}{l}\mathrm{Mn} \\
(\mathrm{ppm})\end{array}$} & \multirow[b]{2}{*}{$\mathrm{Sr} / \mathrm{Ca}$} & \multicolumn{2}{|c|}{ Petrography } \\
\hline & & & & & & & Fossils & Clasts \\
\hline Calcite & $567 \mathrm{~A}-19-1,74-76$ & $\mathrm{Mg}_{0.69}$ & - & 462 & 1291 & 0.0038 & $\begin{array}{l}\text { Planktonic } \\
\text { foraminifers }\end{array}$ & $\begin{array}{l}\text { Clinoptilolite, } \\
\text { chalcedony }\end{array}$ \\
\hline Calcite & $569 \mathrm{~A}-9-1,37-39$ & $\mathrm{Mg}_{0.69}$ & - & 969 & 1108 & 0.0079 & $\begin{array}{l}\text { Benthic, planktonic } \\
\text { foraminifers } \\
\text { radiolarians }\end{array}$ & $\begin{array}{l}\text { Plagioclase, quartz, } \\
\text { smectites }\end{array}$ \\
\hline Calcite & $569 \mathrm{~A}-11-1,31-33$ & $\mathrm{Mg}_{0.69}$ & - & 483 & 2063 & 0.0039 & Radiolarians & $\begin{array}{l}\text { Plagioclase, quartz, } \\
\text { smectites }\end{array}$ \\
\hline Calcite & $570-37-1,30-32$ & $\mathrm{Mg}_{0.57}$ & - & 766 & 1004 & 0.0055 & Radiolarians & $\begin{array}{l}\text { Plagioclase, quartz } \\
\text { smectites }\end{array}$ \\
\hline Calcite & $570-38-1,50-52$ & $\mathrm{Mg}_{0.69}$ & - & 86 & 8596 & 0.00065 & Radiolarians & $\begin{array}{l}\text { Plagioclase, quartz } \\
\text { amphibole }\end{array}$ \\
\hline Calcite & $570-38-1,135-136$ & $\mathrm{Mg}_{0.92}$ & - & 211 & 824 & 0.0017 & Radiolarians & Plagioclase, quartz \\
\hline Calcite & $570-39$, CC (6-9) & $\mathrm{Mg}_{1.26}$ & - & 177 & 1771 & 0.0014 & Radiolarians & $\begin{array}{l}\text { Zeolites, gyrolite, } \\
\text { smectite, chalcedony }\end{array}$ \\
\hline Dolomite & $566-5-3,83-85$ & $\mathrm{Ca}_{53}$ & 0.67 & 552 & 379 & 0.0083 & - & Serpentinite, chromite \\
\hline Dolomite & $567-5-3,105-108$ & $\mathrm{Ca}_{54}$ & 0.50 & 359 & 3812 & 0.0054 & $\begin{array}{l}\text { Planktonic } \\
\text { foraminifers }\end{array}$ & Zeolites, chalcedony \\
\hline Dolomite & $570-19-2,76-78$ & $\mathrm{Ca}_{55}$ & 0.32 & - & - & - & $\begin{array}{l}\text { Benthic foraminifers, } \\
\text { radiolarians, } \\
\text { diatoms }\end{array}$ & $\begin{array}{l}\text { Plagioclase, quartz, } \\
\text { calcite }\end{array}$ \\
\hline Dolomite & $570-27-1,10-12$ & $\mathrm{Ca}_{51}$ & 1.28 & 228 & 623 & 0.0034 & Radiolarians & Plagioclase, quartz \\
\hline Aragonite & $566 \mathrm{C}-5-1,1-2$ & $\mathrm{Mg}_{2.2} \mathrm{a}$ & - & 3187 & 523 & 0.0032 & - & $\begin{array}{l}\text { Serpentinite, } \\
\text { calcite }\end{array}$ \\
\hline Aragonite & $566-5-3,100$ & - & - & 6224 & 259 & 0.0063 & - & Aragonite concretion \\
\hline
\end{tabular}

Note: A mineral composition of $\mathrm{Mg}_{0.69}$ means 0.69 mole $\% \mathrm{MgCO}_{3}$ in the calcite. $\mathrm{Ca}_{55}$ means 55 mole $\% \mathrm{CaCO}_{3}$ in the dolomite lattice. Listed in the table is also the calculated $\mathrm{Sr} / \mathrm{Ca}$ mole ratio of a solution in equilibrium with the carbonates analyzed. - indicates not determined or lacking.

${ }^{a}$ Refers to calcite admixtures in the sample.

\section{Accessory Minerals}

The amphiboles identified in the slope sediments off Guatemala have d-spacings (110) and (151) of about 8.42 $\AA$ and $2.705 \AA$, respectively. The amphiboles were identified optically as greenish brown hornblende exhibiting a strong pleochroism, an optic angle of 60 to $70^{\circ}$, and an extinction angle $\mathrm{Z} \wedge \mathrm{C}$ of 10 to $20^{\circ}$. Second in abundance are clino- and orthopyroxenes that were identified optically as augite and hypersthene, respectively. Epidote is also common and occurs in andesitic lithics (570$35-2,70-75 \mathrm{~cm})$. Zircon, rutile, and apatite are abundant, whereas biotite and olivine are rare. The slope sediments that are associated with ophiolitic rocks (Sites $566,567,569$, and 570 ) contain additional heavy minerals: chromite is the main accessory. Bronzite, actinolite, chlorite, and some olivine are abundant in these sediment sections. Pyrite and limonitic aggregates are the dominant opaque minerals in the slope sediments.

A pyrite concretion with a diameter of $5 \mathrm{~cm}$ was detected in a Hole 569A sediment (569A-10-1, 0-2 cm); it also contains some gypsum. In the upper sediments, pyrite appears only as irregular blebs. In deeper sediments, pyrite forms globular to framboidal aggregates that often fill cavities of radiolarian and foraminiferal skeletons. In the basal sediments of Holes 569A and 570 the pyrite occurs as cubic crystals. Brownish micronodules of phosphorite, partly fish remains, were found in many samples.

Etching of mafic heavy minerals (amphiboles and pyroxenes) is absent in the upper parts of the sediment section but shows a distinct increase toward the oldest sediments (Oligocene, Eocene). In the consolidated sediments of Holes 566, 567, 569, 569A, and 570, mafic heavy min- erals (pyroxenes, amphiboles) have been partly replaced by smectites.

Calculation of saturation indexes for pyroxenes (diopside and enstatite), olivine, and gypsum, as well as the phosphates strengite and vivianite, yielded a strong undersaturation. The interstitial waters investigated are oversaturated for apatite in the upper sediment sections.

The frequency of major and minor elements is more or less constant throughout the sediment columns. The most abundant elements-silica and aluminum-range between 60 and $65 \%$ and 18 and $20 \%$, respectively (Table 2). Only the sediments of Site 567 containing serpentinitic mud admixtures have a different bulk chemistry. This is shown by high $\mathrm{MgO}, \mathrm{Cr}$, and Ni contents. On the other hand, the $\mathrm{TiO}_{2}, \mathrm{Zr}$, and $\mathrm{Y}$ contents are low in these ultramafic rocks and their related sediments (Table 2). Hole 569 and 569A sediments younger than Oligocene show unusually high amounts of $\mathrm{Cr}$ and $\mathrm{Ni}$. This is apparent in a $\mathrm{TiO}_{2}-(\mathrm{Zr}+\mathrm{Y})-(\mathrm{Cr}+\mathrm{Ni})$ diagram (Fig. 5B). The chemical composition of sediments from Holes $567,569,569 \mathrm{~A}$, and 570 plot on a line between the $\mathrm{TiO}_{2}$ and $\mathrm{Zr}+\mathrm{Y}$ pole, which extends toward the $\mathrm{Cr}+\mathrm{Ni}$ pole. The sediments of Site 565, offshore Costa Rica, have a separate position from the samples offshore Guatemala (Fig. 5); they are lower in $\mathrm{Cr}$ and $\mathrm{Ni}$ (Table 2). The distribution of muds compared to pure ash layers is shown in the $\mathrm{Zr}-\mathrm{Y}-\mathrm{TiO}_{2}$ diagram (Fig. 5A).

\section{Biogenic Silica}

Biogenic opal-A is an outstanding component of the Guatemalan slope sediments (up to $20 \%$ of the bulk sediment, Heinemann and Füchtbauer, 1982). In the Leg 84 sediments opal-A is only found as microfossil tests, that is, radiolarians, diatoms, sponge spicules, and isolated sili- 
Table 2. XRF-analyses of sediments, serpentinites, serpentinitic muds, and ash layers of Sites 565, 567, 569, and 570.

\begin{tabular}{|c|c|c|c|c|c|c|c|c|c|c|c|c|c|c|}
\hline \multirow[b]{2}{*}{ Element } & \multicolumn{7}{|c|}{ Typical slope sediments } & \multicolumn{3}{|c|}{ Ash layers } & \multicolumn{4}{|c|}{ Typical slope sediment } \\
\hline & $\begin{array}{l}565-3-1, \\
111-119\end{array}$ & $\begin{array}{l}565-6-2 \\
80-82\end{array}$ & $\begin{array}{l}565-11-4, \\
119-121\end{array}$ & $\begin{array}{c}565-17-3 . \\
53-55\end{array}$ & $\begin{array}{c}565-23-5 . \\
37-39\end{array}$ & $\begin{array}{l}565-27-6, \\
130-136\end{array}$ & $\begin{array}{l}565-30-4, \\
26-28\end{array}$ & $\begin{array}{c}568-5-7 . \\
18-20\end{array}$ & $\begin{array}{c}569-3, \mathrm{CC} \\
(54-56)\end{array}$ & $\begin{array}{l}570-2-1, \\
119-121\end{array}$ & $\begin{array}{c}567-1-1 \\
33-34\end{array}$ & $\begin{array}{l}567-4-3 \\
110-112\end{array}$ & $\begin{array}{c}567-7-1 \\
58-60\end{array}$ & $\begin{array}{l}567-9-1, \\
59-60\end{array}$ \\
\hline \multicolumn{15}{|c|}{ Major and minor elements } \\
\hline $\mathrm{SiO}_{2}$ & 60.10 & 63.28 & 62.84 & 63.49 & 64.05 & 62.18 & 62.76 & 74.79 & 72.39 & 74.11 & 64.09 & 68.58 & 64.70 & 65.06 \\
\hline $\mathrm{TiO}_{2}^{2}$ & 1.29 & 1.08 & 1.14 & 1.10 & 1.01 & 1.08 & 1.20 & 0.19 & 0.32 & 0.20 & 0.77 & 0.62 & 0.75 & 0.78 \\
\hline $\mathrm{Al}_{2} \mathrm{O}_{3}$ & 18.33 & 17.95 & 18.65 & 18.06 & 18.74 & 17.05 & 17.71 & 13.92 & 13.79 & 13.83 & 19.80 & 17.01 & 19.16 & 20.14 \\
\hline $\mathrm{Fe}_{2} \mathrm{O}_{3}$ & 10.04 & 8.92 & 9.16 & 8.47 & 8.50 & 10.01 & 10.07 & 1.78 & 3.24 & 1.69 & 6.67 & 4.99 & 6.63 & 6.75 \\
\hline $\mathrm{MnO}$ & 0.09 & 0.06 & 0.06 & 0.06 & 0.04 & 0.08 & 0.08 & 0.08 & 0.07 & 0.12 & 0.07 & 0.08 & 0.05 & 0.05 \\
\hline $\mathrm{MgO}$ & 4.50 & 3.56 & 3.68 & 3.62 & 3.25 & 4.37 & 4.09 & 0.39 & 0.49 & 0.41 & 2.48 & 1.41 & 4.11 & 2.58 \\
\hline $\mathrm{CaO}$ & 1.89 & 0.96 & 1.40 & 1.88 & 0.69 & 2.06 & 0.71 & 1.13 & 2.27 & 1.10 & 1.98 & 1.78 & 0.86 & 1.96 \\
\hline $\mathrm{Na}_{2} \mathrm{O}$ & 1.38 & 1.61 & 0.88 & 1.06 & 1.36 & 1.03 & 1.09 & 3.40 & 3.57 & 3.57 & 1.73 & 2.53 & 1.02 & 1.06 \\
\hline $\mathrm{K}_{2} \mathrm{O}$ & 1.89 & 2.17 & 1.70 & 1.84 & 2.02 & 1.62 & 1.80 & 3.98 & 3.32 & 4.69 & 1.83 & 2.49 & 2.24 & 1.26 \\
\hline $\mathrm{P}_{2} \mathrm{O}_{5}$ & 0.16 & 0.13 & 0.15 & 0.15 & 0.11 & 0.15 & 0.16 & 0.05 & 0.09 & 0.05 & 0.25 & 0.13 & 0.11 & 0.11 \\
\hline $\mathrm{s}^{2}$ & 0.13 & 0.07 & 0.11 & 0.06 & 0.09 & 0.16 & 0.09 & 0.12 & 0.09 & 0.05 & 0.05 & 0.20 & 0.16 & 0.06 \\
\hline $\mathrm{Cl}$ & 0.01 & 0.01 & 0.01 & 0.01 & 0.01 & 0.01 & 0.01 & 0.01 & 0.01 & 0.01 & 0.01 & 0.01 & 0.01 & 0.01 \\
\hline \multicolumn{15}{|c|}{ Trace elements } \\
\hline $\mathrm{v}$ & 240 & 190 & 211 & 214 & 190 & 218 & 220 & 20 & 26 & 18 & 141 & 73 & 136 & 129 \\
\hline $\mathrm{Cr}$ & 144 & 120 & 120 & 124 & 97 & 128 & 130 & 10 & 8 & 23 & 117 & 65 & 85 & 83 \\
\hline Co & 31 & 24 & 26 & 24 & 25 & 29 & 30 & 1 & 7 & 1 & 17 & 12 & 16 & 17 \\
\hline $\mathrm{Ba}$ & 559 & 761 & 965 & 1017 & 95 & 847 & 889 & 934 & 1377 & 741 & 807 & 695 & 1050 & 608 \\
\hline $\mathrm{Ni}$ & 85 & 99 & 63 & 60 & 70 & 94 & 98 & 202 & 230 & 167 & 82 & 58 & 71 & 49 \\
\hline $\mathrm{Cu}$ & 102 & 118 & 109 & 72 & 102 & 98 & 99 & 26 & 40 & 61 & 261 & 111 & 77 & 82 \\
\hline $\mathrm{Zn}$ & 85 & 214 & 196 & 169 & 248 & 181 & 205 & 51 & 75 & 58 & 463 & 166 & 203 & 244 \\
\hline $\mathrm{Rb}$ & 49 & 54 & 55 & 52 & 52 & 49 & 51 & 122 & 69 & 124 & 86 & 55 & 82 & 58 \\
\hline $\mathrm{Sr}$ & 321 & 323 & 258 & 235 & 306 & 255 & 250 & 128 & 194 & 72 & 275 & 192 & 230 & 373 \\
\hline $\mathrm{Y}$ & 23 & 19 & 38 & 23 & 22 & 28 & 27 & 14 & 28 & 25 & 27 & 34 & 25 & 22 \\
\hline $\mathrm{Zr}$ & 130 & 123 & 125 & 123 & 123 & 126 & 119 & 82 & 183 & 119 & 142 & 186 & 143 & 174 \\
\hline $\mathrm{Nb}$ & 8 & 8 & 5 & 6 & 4 & 6 & 6 & 4 & 10 & 9 & 6 & 7 & 5 & 5 \\
\hline
\end{tabular}

Note: Sample numbers show hole-core-section, $\mathrm{cm}$ interval. Major and minor elements are in weight percent, trace elements in ppm. Total iron is calculated as Fe ${ }_{2} \mathrm{O}_{3}$. The analyses are calculated to a water and carbonate-free basis.

coflagellates. The measured refraction indexes of opal-A sponge spicules show an increase of refraction toward older sediments (Table 3 ). In the unconsolidated sediments of Leg 84 only opal-A occurs.

Isotropic opal-A can still be recognized in an early Eocene sediment at Site 570. In this sample (570-37-1, 15-20 cm), preserved opal-A radiolarian tests with an average diameter of 100 to $200 \mu \mathrm{m}$ are embedded in a marly groundmass (Plate 1, Fig. 1). The tests are filled with a blocky Fe-calcite cement. However, in the next core also containing early Eocene sediments, the radiolarian tests are completely altered to chalcedony. This can be observed in Sample 570-38-1, 50-52 cm, a calcilutite interrupted by fine sand turbidites including shallow-water foraminiferal tests. Some opal-CT occur in this sand. The radiolarian skeletons in the calcilutite have an average diameter of 30 to $90 \mu \mathrm{m}$. Chalcedony and traces of opal-CT were identified in all consolidated sediments of Cores 570-38 and 570-39. Chalcedony occurs as a successor of opal in the Upper Cretaceous sediment of Core 19, Hole 567.

Etching of siliceous skeletons and mineral precipitation (Plate 3, Fig. 3) in these tests can be observed in several samples (568-43-2, 48-50 cm, and 569A-9-2, 0-2 $\mathrm{cm}$ ). The precipitates contain $\mathrm{Si}$ and $\mathrm{Al}$ and, as minor components, alkali and earth alkali elements, which would point to clays or zeolites. The widespread occurrence of pyrite as a filling in radiolarian and diatom tests was mentioned earlier. The calculation of saturation indexes for amorphous silica yields a low oversaturation in the upper sediment section that changes to a distinct undersaturation in the lowermost interstitial water samples. The opal-A successor opal-CT is undersaturated in almost all interstitial water samples, whereas all interstitial waters are oversaturated for chalcedony and quartz.

\section{Volcanic Glass}

Volcanic glass is abundant in all fractions, as indicated by the broad reflection between $19^{\circ}-21^{\circ}$ and $32^{\circ}$ (2Ө). This reflection also was recognized in the $<2-\mu \mathrm{m}$ fraction. Volcanic glass is one of the main constituents of the slope sediments offshore Guatemala. The refractive index of most of the volcanic glass is about 1.50 (Table 4). Only a few shards with a refractive index of about 1.52 were identified (Table 4). Brownish glass shards with a basaltic composition are very rare.

According to Schmincke (1982), the glass shards with a refractive index about 1.50 have an $\mathrm{SiO}_{2}$ content of about $70 \%$, indicating rhyolitic composition, whereas the shards with a refractive index about 1.52 have an $\mathrm{SiO}_{2}$ content of about $65 \%$, corresponding to dacitic composition. The rhyolitic composition of glass shards with a refractive index about 1.50 is also confirmed by X-ray fluorescence (Table 2). According to their refractive index, the glass shards from sediments off Costa Rica have slightly higher $\mathrm{SiO}_{2}$ contents (Table 4).

Detailed electron microscopy yielded three main types of rhyolitic glass shards. The most frequent type is a tabular pumice with a typical conchoidal fracture and a lack of bubble junctions (Plate 4, Fig. 1). Second in abundance is a type with strongly developed bubble junctions and bubble wall junctions (Plate 4, Fig. 2). These two types are predominant in the slope sediments, and the third type shows large, elongated vesicles (Plate 4, Fig. 3). 
Table 2. (Continued).

\begin{tabular}{|c|c|c|c|c|c|c|c|c|c|c|c|c|c|c|}
\hline \multirow[b]{2}{*}{$\begin{array}{c}567-12-2 \\
68-70\end{array}$} & \multicolumn{4}{|c|}{ Serpentinitic muds } & \multicolumn{2}{|c|}{ Serpentinites } & \multicolumn{8}{|c|}{ Typical slope sediments } \\
\hline & $\begin{array}{c}567-14-2 \\
131-133\end{array}$ & $\begin{array}{c}567-17-1 \\
110-112\end{array}$ & $\begin{array}{c}(<63 \mu \mathrm{m}) \\
567-7-2, \\
77-79\end{array}$ & $\begin{array}{c}(>63 \mu \mathrm{m}) \\
567-7-2, \\
77-79\end{array}$ & $\begin{array}{l}567-14-2 \\
140-142\end{array}$ & $\begin{array}{c}567-17-3 \\
55-60\end{array}$ & $\begin{array}{l}569-2-1, \\
112-114\end{array}$ & $\begin{array}{c}567-6-3 \\
55-57\end{array}$ & $\begin{array}{c}567-9-1 \\
9-10\end{array}$ & $\begin{array}{c}569-12-4 \\
60-62\end{array}$ & $\begin{array}{l}569-15-2 \\
125-127\end{array}$ & $\begin{array}{l}569-18-1 \\
136-138\end{array}$ & $\begin{array}{c}569-23-3 \\
62-64\end{array}$ & $\begin{array}{c}569-27-1, \\
53-55\end{array}$ \\
\hline 65.99 & 54.20 & 46.59 & 48.37 & 40.80 & 43.07 & 42.56 & 61.70 & 63.07 & 61.21 & 62.08 & 61.62 & 65.29 & 65.53 & 63.46 \\
\hline 0.83 & 0.93 & 0.01 & 0.02 & 0.04 & 0.04 & 0.01 & 0.86 & 0.85 & 0.82 & 0.90 & 0.83 & 0.70 & 0.76 & 0.65 \\
\hline 18.88 & 17.34 & 0.39 & 0.78 & 1.49 & 1.34 & 0.68 & 20.71 & 19.83 & 19.55 & 19.44 & 19.78 & 18.48 & 20.51 & 18.65 \\
\hline 7.77 & 9.88 & 6.59 & 5.73 & 0.12 & 10.00 & 9.23 & 9.76 & 8.57 & 8.22 & 8.14 & 8.88 & 6.83 & 6.53 & 11.83 \\
\hline 0.33 & 0.18 & 0.09 & 0.05 & 0.32 & 0.13 & 0.14 & 0.08 & 0.07 & 0.09 & 0.06 & 0.08 & 0.10 & 0.06 & 0.05 \\
\hline 2.27 & 12.05 & 44.96 & 43.67 & 38.91 & 44.60 & 46.26 & 2.95 & 3.02 & 2.46 & 3.56 & 2.19 & 1.68 & 1.75 & 1.30 \\
\hline 0.33 & 1.03 & 0.03 & 0.58 & 17.21 & 0,10 & 0.45 & 0.38 & 0.56 & 2.67 & 2.35 & 2.66 & 1.15 & 1.47 & 0.46 \\
\hline 1.23 & 1.39 & 0.03 & 0.06 & 0.12 & 0.02 & 0.01 & 1.48 & 1.55 & 2.60 & 1.39 & 1.75 & 2.56 & 1.43 & 1.35 \\
\hline 1.73 & 2.45 & 0.01 & 0.02 & 0.07 & 0.01 & 0.01 & 1.35 & 1.72 & 1.69 & 1.40 & 1.53 & 2.44 & 1.50 & 1.84 \\
\hline 0.25 & 0.16 & 0.01 & 0.02 & 0.04 & 0.01 & 0.01 & 0.21 & 0.25 & 0.24 & 0.18 & 0.21 & 0.21 & 0.11 & 0.11 \\
\hline 0.10 & 0.18 & 0.48 & 0.18 & 0.21 & 0.15 & 0 & 0.06 & 0.05 & 0.05 & 0.09 & 0.07 & 0.12 & 0.09 & 0.11 \\
\hline 0.02 & 0.01 & 0.01 & 0.01 & 0.01 & 0.02 & 0.02 & 0.01 & 0.01 & 0.01 & 0.01 & 0.01 & 0.01 & 0.01 & 0.01 \\
\hline 148 & 189 & 31 & 23 & 41 & 39 & 40 & 126 & 145 & 194 & 182 & 155 & 101 & 135 & 109 \\
\hline 67 & 124 & 3076 & 1732 & 3285 & 1807 & 3107 & 1728 & 1333 & 1150 & 999 & 1680 & 1694 & 672 & 121 \\
\hline 17 & 27 & 68 & 54 & 54 & 71 & 61 & 29 & 25 & 27 & 23 & 28 & 20 & 19 & 32 \\
\hline 592 & 719 & 0 & 47 & 239 & 1 & 0 & 681 & 1413 & 1123 & 959 & 660 & 776 & 687 & 701 \\
\hline 70 & 84 & 4528 & 2721 & 1776 & 3047 & 2478 & 882 & 774 & 579 & 453 & 742 & 830 & 345 & 153 \\
\hline 157 & 242 & 60 & 91 & 12 & 76 & 61 & 78 & 113 & 97 & 598 & 66 & 42 & 53 & 38 \\
\hline 225 & 150 & 48 & 232 & 90 & 64 & 66 & 225 & 238 & 186 & 210 & 171 & 156 & 184 & 294 \\
\hline 78 & 44 & 7 & 8 & 12 & 11 & 9 & 58 & 68 & 56 & 61 & 51 & 72 & 57 & 75 \\
\hline 1012 & 193 & 7 & 23 & 245 & 10 & 10 & 370 & 297 & 432 & 244 & 302 & 319 & 226 & 184 \\
\hline 32 & 24 & 0 & 2 & 1 & 0 & 0 & 23 & 26 & 28 & 23 & 27 & 29 & 23 & 25 \\
\hline 162 & 110 & 9 & 14 & 21 & 11 & 14 & 153 & 145 & 120 & 152 & 136 & 191 & 134 & 136 \\
\hline 6 & 1 & 1 & 1 & 1 & 1 & 1 & 16 & 13 & 14 & 11 & 15 & 19 & 22 & 7 \\
\hline
\end{tabular}

The infrared spectra of glass shards (Fig. 6) show a peak at about $3750 \mathrm{~cm}^{-1}$, which is attributed to water, that is, to the fundamental $\mathrm{O}-\mathrm{H}$ stretching vibration that can be produced by $\mathrm{X}-\mathrm{OH}$ or $\mathrm{H}-\mathrm{O}-\mathrm{H}$ groups. The water content evaluated from this peak ranges from 0.5 to $2 \%$ and is comparable to values in rhyolitic glass investigated by Stolper (1982). The studied samples lack any evidence for a systematic change of water content with increasing age of the glass sample.

The infrared spectra of the glass shards investigated from the sites off Guatemala are very similar to those of synthetic $\mathrm{Na}_{2} \mathrm{O}-\mathrm{Al}_{2} \mathrm{O}_{3}-\mathrm{SiO}_{2}$ glass investigated by Day and Rindone (1962). According to these authors the main peak in the Leg 84 glass spectra at $1000-1200 \mathrm{~cm}^{-1}$ is attributed to the $\mathrm{Si}-\mathrm{O}$ vibration, whereas the band at 780 $790 \mathrm{~cm}^{-1}$ is attributed to the $\mathrm{Si}-\mathrm{O}-\mathrm{Si}$ vibration. Both bands would show a shift toward larger wave length with increasing alkali content (Day and Rindone, 1962). The glass samples investigated do not show any shift of these bands with increasing sub-bottom depth or age of the sediment (Fig. 6).

Dissolution pits can be observed on the surfaces of glass shards under the electron microscope. The glass shards in the sediments of Holes 569 and 569A show an increase of dissolution pits from Pleistocene samples (5693,CC [9-10 cm]) (Plate 4, Fig. 6) to the oldest Eocene samples (569A-9-2, 0-2 cm) (Plate 4, Fig. 4). Observations under a very high magnification show that there is no precipitation of authigenic minerals or alteration of the glass material in the areas of the dissolution pits (Plate 4, Fig. 5). Analyses with an energy-dispersive system of the electron microscope further prove that there are no perceptible differences between the chemistry of pit-bearing and that of pit-lacking areas.

\section{Zeolites}

The occurrence of zeolites in the sediments of the Middle America slope was documented by Heinemann and Füchtbauer (1982) and Kurnosov et al. (1982). The first authors identified heulandite and clinoptilolite in the slope sediments, whereas the second identified only clinoptilolite.

Analcime and the hydrous Ca-silicate gyrolite $\left[\mathrm{Ca}_{4}\right.$ $\left(\mathrm{Si}_{6} \mathrm{O}_{15}\right)(\mathrm{OH})_{2} \times 2 \mathrm{H}_{2} \mathrm{O}$ ] were identified by X-ray diffraction. The X-ray diffraction pattern of a gyrolite- and clinoptilolite-bearing sample is shown in Figure 7A and 7B.

The X-ray diffraction studies indicate that clinoptilolite only occurs in the slope sediments off Guatemala; at Site 565 off Costa Rica, heulandite occurs in all samples and grain size fractions, with a maximum in the 6.3- to $20-\mu \mathrm{m}$ fraction. Additional analcime occurs beginning with Sample 565-17-3, 53-55 cm.

There are only a few occurrences of clinoptilolite in the Recent-Miocene sediments off Guatemala. Clinoptilolite is completely absent in the Site 568 sediments. However, a frequent occurrence of clinoptilolite can be recognized in the upper Oligocene - lower Eocene sediments of Holes 569, 569A, and 570. In the consolidated Eocene sediments at Site $570(570-39-1,115-117 \mathrm{~cm})$, clinoptilolite occurs as an infilling of radiolarian tests, as isolated crystals, as fissure filling, and as a replacement of the smectite groundmass (Plate 2, Fig. 2.). Fissures in Sample 570-39,CC (6-9) cm were filled first by clinoptilolite and then by gyrolite and analcime (Plate 1, Fig. 6.). The marly groundmass in this sample is partly replaced by leaflike aggregates of gyrolite and nonidiomorphic analcime. Gyrolite was identified only in Sam- 
Table 2. (Continued).

\begin{tabular}{|c|c|c|c|c|c|c|c|c|c|c|c|c|c|c|}
\hline \multirow[b]{2}{*}{ Element } & \multicolumn{14}{|c|}{ Typical slope sediments } \\
\hline & $\begin{array}{c}569-4-2 \\
65-67\end{array}$ & $\begin{array}{c}569-6-1 \\
54-56\end{array}$ & $\begin{array}{c}569-9-2 \\
0-2\end{array}$ & $\begin{array}{c}570-4-3 \\
12-14\end{array}$ & $\begin{array}{c}570-9-1, \\
30-32\end{array}$ & $\begin{array}{c}570-14-6 \\
14-16\end{array}$ & $\begin{array}{c}570-19-2 \\
76-78\end{array}$ & $\begin{array}{c}570-23-4 \\
30-32\end{array}$ & $\begin{array}{c}570-25-3 \\
60-62\end{array}$ & $\begin{array}{c}570-29-2 \\
74-76\end{array}$ & $\begin{array}{l}570-34-2 \\
114-116\end{array}$ & $\begin{array}{l}570-38-1 \\
132-134\end{array}$ & $\begin{array}{l}570-39-1, \\
138-158\end{array}$ & $\begin{array}{c}570-39-1 \\
115-117\end{array}$ \\
\hline \multicolumn{15}{|c|}{ Major and minor elements } \\
\hline $\mathrm{SiO}_{2}$ & 63.81 & 63.59 & 68.11 & 61.66 & 62.53 & 60.36 & 59.96 & 62.59 & 63.81 & 62.21 & 59.81 & 59.59 & 60.36 & 66.30 \\
\hline $\mathrm{TiO}_{2}$ & 0.82 & 0.86 & 0.69 & 0.80 & 0.89 & 0.91 & 0.83 & 0.77 & 0.79 & 0.84 & 0.88 & 1.09 & 0.96 & 0.43 \\
\hline $\mathrm{Al}_{2} \mathrm{O}_{3}$ & 21.52 & 21.41 & 14.89 & 21.16 & 21.23 & 21.26 & 20.73 & 21.27 & 20.67 & 21.00 & 19.68 & 17.57 & 16.81 & 10.87 \\
\hline $\mathrm{Fe}_{2} \mathrm{O}_{3}$ & 7.25 & 7.28 & 6.96 & 7.68 & 7.95 & 8.40 & 7.09 & 7.23 & 6.76 & 7.32 & 8.2 & 8.97 & 10.75 & 5.13 \\
\hline $\mathrm{MnO}$ & 0.04 & 0.05 & 0.07 & 0.08 & 0.07 & 0.08 & 0.08 & 0.08 & 0.08 & 0.08 & 0.08 & 0.14 & 0.11 & 0.16 \\
\hline $\mathrm{MgO}$ & 1.74 & 2.13 & 2.47 & 2.78 & 2.73 & 2.96 & 2.90 & 1.97 & 2.41 & 1.58 & 2.81 & 3.9 & 4.77 & 9.68 \\
\hline $\mathrm{CaO}$ & 1.76 & 0.33 & 2.66 & 1.38 & 0.50 & 2.30 & 3.57 & 1.42 & 0.41 & 1.98 & 3.81 & 3.27 & 1.55 & 2.77 \\
\hline $\mathrm{Na}_{2} \mathrm{O}$ & 1.14 & 1.47 & 1.47 & 2.21 & 1.84 & 1.62 & 1.96 & 2.1 & 2.47 & 2.26 & 2.05 & 2.63 & 1.64 & 3.38 \\
\hline $\mathrm{K}_{2} \mathrm{O}$ & 1.44 & 2.30 & 1.65 & 1.55 & 1.48 & 1.41 & 1.81 & 1.71 & 1.85 & 1.76 & 1.78 & 2.24 & 2.39 & 0.80 \\
\hline $\mathrm{P}_{2} \mathrm{O}_{5}$ & 0.14 & 0.22 & 0.58 & 0.33 & 0.34 & 0.29 & 0.69 & 0.38 & 0.35 & 0.55 & 0.47 & 0.24 & 0.22 & 0.12 \\
\hline $\mathrm{S}^{2-2}$ & 0.16 & 0.07 & 0.08 & 0.07 & 0.07 & 0.05 & 0.08 & 0.08 & 0.08 & 0.08 & 0.08 & 0.06 & 0.03 & 0.12 \\
\hline $\mathrm{CI}$ & 0.01 & 0.01 & 0.02 & 0.01 & 0.01 & 0.01 & 0.02 & 0.02 & 0.01 & 0.01 & 0.01 & 0.01 & 0.01 & 0.01 \\
\hline \multicolumn{15}{|c|}{ Trace elements } \\
\hline V & 134 & 145 & 299 & 104 & 128 & 134 & 169 & 100 & 137 & 134 & 168 & 188 & 163 & 125 \\
\hline $\mathrm{Cr}$ & 196 & 81 & 371 & 1264 & 495 & 746 & 586 & 1066 & 617 & 818 & 1000 & 371 & 77 & 312 \\
\hline Co & 18 & 18 & 12 & 20 & 20 & 22 & 12 & 23 & 18 & 17 & 24 & 24 & 34 & 16 \\
\hline $\mathrm{Ba}$ & 575 & 1450 & 590 & 528 & 517 & 560 & 578 & 641 & 710 & 760 & 694 & 887 & 313 & 703 \\
\hline $\mathrm{Ni}$ & 111 & 118 & 201 & 654 & 321 & 492 & 293 & 550 & 339 & 447 & 552 & 252 & 229 & 139 \\
\hline $\mathrm{Cu}$ & 38 & 81 & 92 & 43 & 648 & 114 & 46 & 187 & 37 & 83 & 83 & 313 & 666 & 48 \\
\hline $\mathrm{Zn}$ & 188 & 198 & 506 & 171 & 268 & 213 & 186 & 228 & 168 & 236 & 198 & 209 & 250 & 62 \\
\hline $\mathrm{Rb}$ & 63 & 86 & 71 & 60 & 61 & 58 & 77 & 65 & 56 & 71 & 66 & 64 & 78 & 20 \\
\hline Sr & 209 & 424 & 1227 & 63 & 902 & 809 & 713 & 862 & 661 & 657 & 462 & 414 & 2067 & 723 \\
\hline$Y$ & 27 & 30 & 38 & 25 & 27 & 26 & 31 & 32 & 30 & 31 & 28 & 36 & 27 & 18 \\
\hline $\mathrm{Zr}$ & 161 & 174 & 145 & 180 & 171 & 173 & 184 & 178 & 161 & 136 & 160 & 209 & 158 & 55 \\
\hline $\mathrm{Nb}$ & 7 & 5 & 5 & 11 & 9 & 11 & 11 & 11 & 8 & 9 & 12 & 7 & 5 & 0 \\
\hline
\end{tabular}
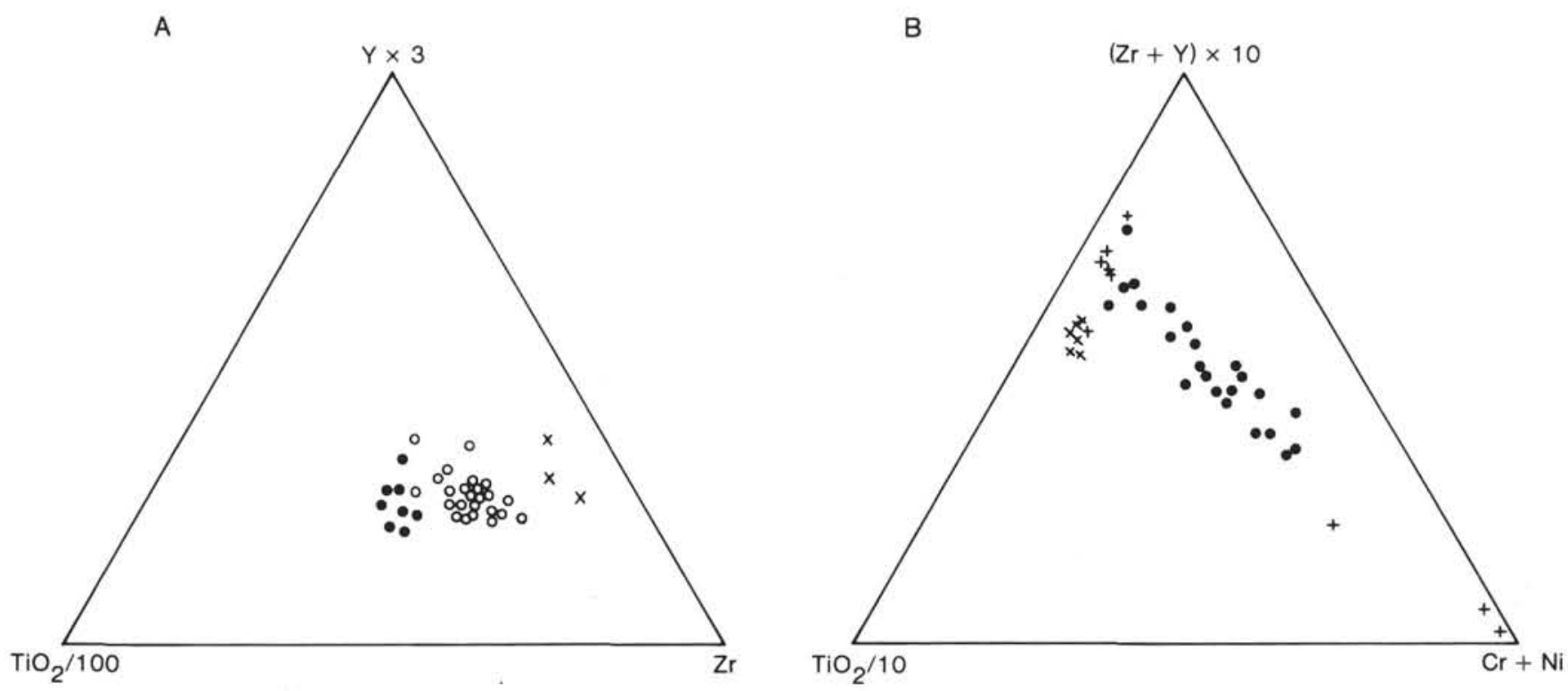

Figure 5. Plots of sediment composition in (A) a $\mathrm{TiO}_{2}-\mathrm{Zr}-\mathrm{Y}$ diagram; and $(\mathrm{B})$ a $(\mathrm{Zr}+\mathrm{Y})-\mathrm{TiO}_{2}-(\mathrm{Cr}+\mathrm{Ni})$ diagram. In $5 \mathrm{~A}, \mathrm{O}=$ slope sediments of Sites 567, 569, and 570; $=$ slope sediment of Site 565, and $X=$ ash layers of Sites 568, 569, and 570. In 5B, $X=$ slope sediments of Site 565; $+=$ sediments, serpentinites, and serpentinitic muds of Site 567; and $\bullet=$ slope sediments of Sites 569 and 570.

ple $570-39, \mathrm{CC}(6-9 \mathrm{~cm})$, the basal sediment above the serpentinitic basement at Site 570 .

Analcime was identified in all consolidated Site 570 sediments. The occurrence of analcime in the unconsolidated sediments of Site 567 is related to sediments including serpentinitic mud. In these Miocene sediments, traces of clinoptilolite were identified beside analcime.

Calculations with the WATEQ program show that the interstitial waters in the slope sediments off Costa Rica and Guatemala are highly oversaturated for analcime.
Solubility indexes of heulandite and clinoptilolite were not calculated because thermochemical data are lacking. All interstitial waters investigated plot in the stability field of $(\mathrm{Na}, \mathrm{K})$-clinoptilolite, as shown in $\log \left[\mathrm{Na}^{+} /\right.$ $\left.\mathrm{H}^{+}\right]$and $\log \left[\mathrm{K}^{+} / \mathrm{H}^{+}\right]$versus $\log \mathrm{H}_{4} \mathrm{SiO}_{4}$ diagrams (Fig. 8 ), according to Cosgrove and Papavassiliou (1979).

\section{Clay Minerals}

According to Table 5, the main clay mineral is smectite; only minor amounts of illite, kaolinite, and chlorite 
Table 3. Retractive indexes of sponge spicules.

\begin{tabular}{|c|c|c|c|}
\hline $\begin{array}{c}\text { Sample } \\
\text { (interval in } \mathrm{cm} \text { ) }\end{array}$ & $\begin{array}{l}\text { Approximate } \\
\text { sub-bottom } \\
\text { depth }(\mathrm{m})\end{array}$ & Stratigraphy & $\begin{array}{l}\text { Refractive } \\
\text { index }\end{array}$ \\
\hline \multicolumn{4}{|l|}{ Hole 568} \\
\hline $12-5,102-104$ & 106 & Pleistocene & 1.4497 \\
\hline $22-5,50-52$ & 202 & $\begin{array}{l}\text { Pliocene-late } \\
\text { Miocene }\end{array}$ & 1.4508 \\
\hline $41-4,70-72$ & 385 & early Miocene & 1.4518 \\
\hline \multicolumn{4}{|l|}{ Hole 569} \\
\hline $9-1,55-57$ & 69 & Pliocene-Miocene & 1.4496 \\
\hline $15-2,125-127$ & 127 & early Miocene & 1.4499 \\
\hline $27-1,53-55$ & 241 & late Oligocene & 1.4510 \\
\hline \multicolumn{4}{|l|}{ Hole 570} \\
\hline $9-1,30-32$ & 76 & Pleistocene & 1.4470 \\
\hline $19-2,76-78$ & 175 & late Pliocene & 1.4475 \\
\hline $38-1,107-109$ & 356 & early Pliocene & 1.4496 \\
\hline
\end{tabular}

Table 4. Refractive indices of colorless glass shards.

\begin{tabular}{|c|c|}
\hline $\begin{array}{c}\text { Sample } \\
\text { (hole-core-section, cm interval) }\end{array}$ & $\begin{array}{l}\text { Refractive } \\
\text { index }\end{array}$ \\
\hline $565-3-1,111-115$ & 1.4967 \\
\hline $565-6-2,80-82$ & 1.4962 \\
\hline $565-11-4,119-123$ & 1.4965 \\
\hline $565-30-4,26-28$ & 1.4971 \\
\hline $567-1-1,33-34$ & 1.4998 \\
\hline $567-2-4,22-24$ & 1.5001 \\
\hline $567-3-1,112-113$ & 1.5012 \\
\hline $567-4-3,110-112$ & 1.4996 \\
\hline $567-9-5,143-144$ & 1.5034 \\
\hline $567-17-1,32-35$ & 1.5024 \\
\hline $568-1-1,80-82$ & $1.4970,1.5000$ \\
\hline $568-12-5,102-104$ & 1.5248 \\
\hline $568-22-5,50-52$ & $1.5041,1.5232$ \\
\hline $568-38-6,82-84$ & 1.4932 \\
\hline $568-41-4,70-72$ & 1.5041 \\
\hline $568-44-3,114-118$ & $1.5041,1.5252$ \\
\hline $569-1-1,104-106$ & 1.4993 \\
\hline $569-3, \mathrm{CC}(9-10)$ & 1.4933 \\
\hline $569-6-3,95-97$ & 1.4932 \\
\hline $569-12-4,60-62$ & 1.4921 \\
\hline $569-15-2,125-127$ & $1.4942,1.501$ \\
\hline $569-18-1,136-138$ & 1.5071 \\
\hline $569-27-1,53-55$ & 1.5042 \\
\hline $569 A-2-2,1-2$ & 1.5001 \\
\hline $570-1-4,6-8$ & 1.4983 \\
\hline $570-9-1,30-32$ & 1.4981 \\
\hline $570-19-2,76-78$ & 1.500 \\
\hline $570-29-3,74-76$ & 1.498 \\
\hline $570-38-1,107-109$ & 1.4972 \\
\hline
\end{tabular}

are present in the samples investigated. Smectite-illite mixed layers, saponite, chlorite, and large amounts of serpentine occur in the sediments that were called "serpentinitic muds" (Table 5). A similar clay mineral paragenesis has been determined at Site 566 .

The smectite in most of the sediments can be called montmorillonite, using criteria discussed by Thorez (1975). This is also proved by a dioctahedral (060) figure of about 1.500 A (Table 5). In the sediments of Sites 566

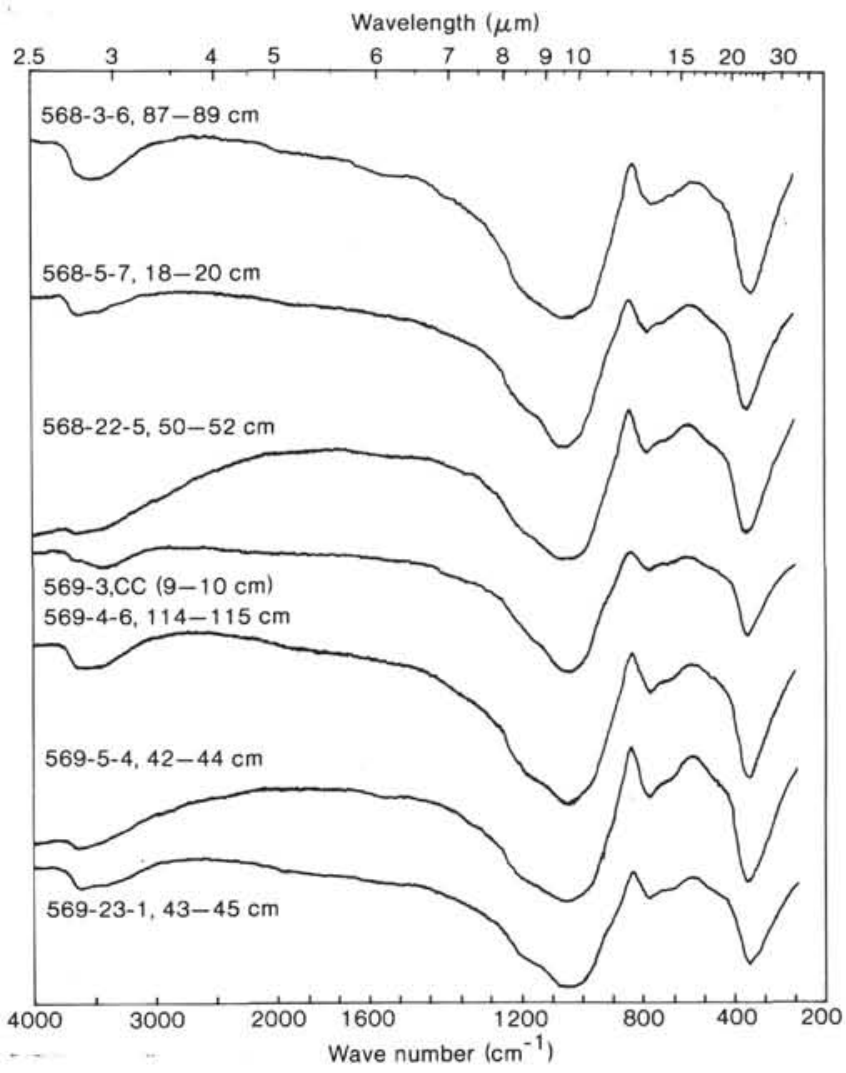

Figure 6. Infrared spectra of glass samples investigated. Site 568 samples range from Pleistocene to lower Pliocene (from 21 to $200 \mathrm{~m}$ sub-bottom depth). Site 569 samples range from Pleistocene to lower Miocene (20 - $210 \mathrm{~m}$ sub-bottom depth).

and 567 , trioctahedral smectites with $\mathrm{d}(060)=1.51$ $1.53 \AA$ occur as well. The average $(001) \mathrm{d}$-spacing of montmorillonite is $14-15 \AA$ and expands to about $17 \AA$ after treatment with glycol.

In sediments older than Pliocene, the (002) and (003) d-spacings of smectite begin to develop, and the first nonexpandable illite layers occur in middle to lower Miocene sediments (Table 5). The increase of illite layers corresponds to an increase of $\mathrm{K}_{2} \mathrm{O}$ weight percent in the $<2-\mu$ m samples (Fig. 9).

Site 565 off Costa Rica is exceptional, because the highest percentage of nonexpandable layers is found in Pleistocene and Pliocene sediments. In the untreated $<2$ $\mu \mathrm{m}$ samples the $15-\AA$ amplitude of smectite increases with sediment age.

The occurrence of nonexpandable layers in the montmorillonites correlates with an increasing $17-\AA$ amplitude in the glycolated sample (Fig. 10). The height/width ratio of glycolated smectite (001) d-spacing increases with increasing sediment age (Fig. 11). An increase of height/ width ratio with increasing sediment age can also be observed for the (060) d-spacings (Fig. 12). It is noteworthy that smectite from pure ash layers shows a considerable lower height/width ratio than the smectites in the adjacent muds. After heating the montmorillonite to $350^{\circ} \mathrm{C}$ or $500^{\circ} \mathrm{C}$, the $14-15 \AA$ structure collapses, because of a loss of interlayer water, to a $10-\AA$ structure. 
A

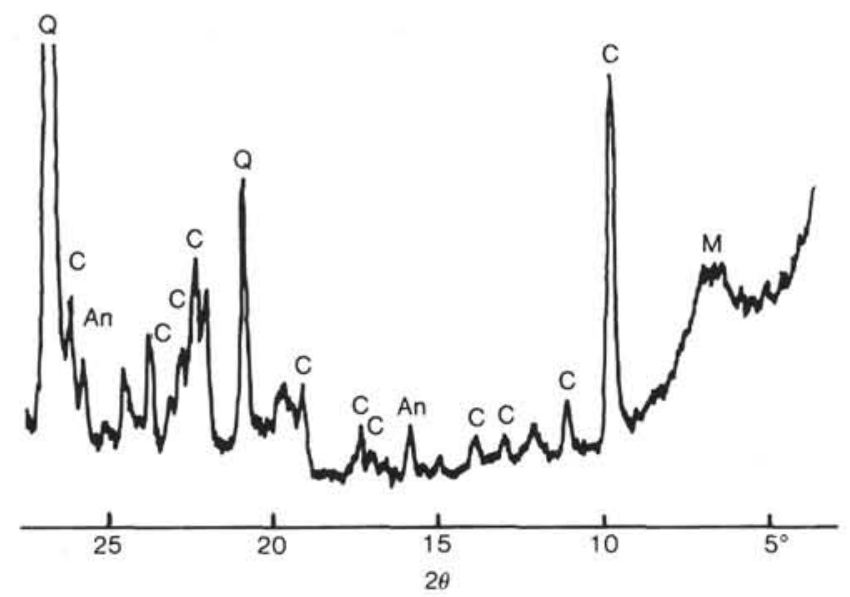

B

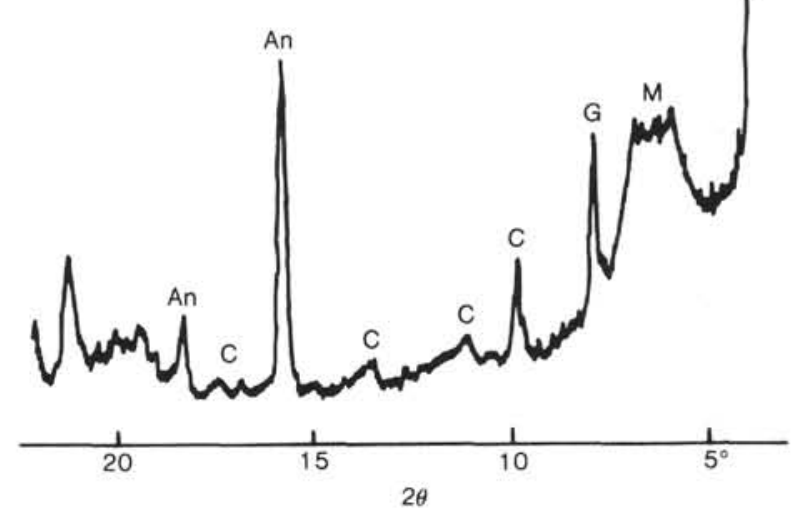

Figure 7. A. X-ray diffractogram of a clinoptilolite-bearing sample (570-39-1, 115-117 cm). B. X-ray diffractogram of a gyrolite-bearing sample (570-39, CC [6-9 cm]). (Q, C, An, G, and M refer to quartz, clinoptilolite, analcime, gyrolite, and montmorillonite, respectively.)
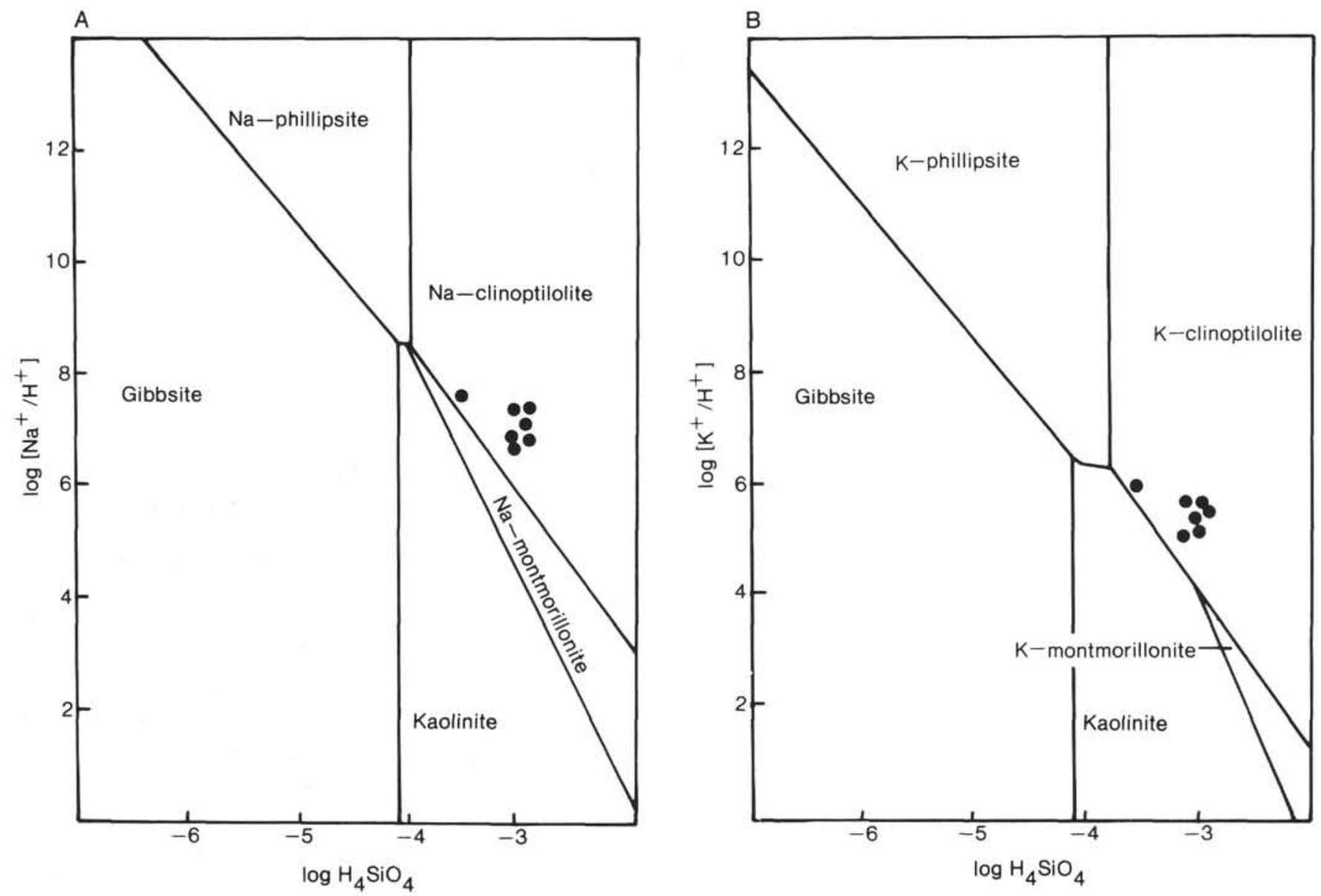

Figure 8. Stability fields for A. Na-silicates and B. K - silicates in log-activity diagrams, according to Cosgrove and Papavassiliou (1979). 
Table 5. Clay minerals in Leg $84<2-\mu \mathrm{m}$ fractions.

\begin{tabular}{|c|c|c|c|c|c|c|c|c|c|c|}
\hline \multirow[b]{2}{*}{$\begin{array}{c}\text { Sample } \\
\text { (core-section, cm interval) }\end{array}$} & \multicolumn{3}{|c|}{ Clay minerals $(\%)$} & \multicolumn{3}{|c|}{ Swelling minerals (A) } & \multirow[b]{2}{*}{ Chlorite } & \multirow[b]{2}{*}{$\begin{array}{l}\text { Nonexpandable } \\
\text { layers }(\%)\end{array}$} & \multirow[b]{2}{*}{ Stratigraphy } & \multirow[b]{2}{*}{ Remarks } \\
\hline & $\begin{array}{l}\text { Smec- } \\
\text { tite }\end{array}$ & 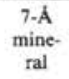 & Illite & $\begin{array}{c}\text { (001) } \\
\text { Origi- } \\
\text { nal }\end{array}$ & $(060)$ & $\begin{array}{l}(001) \\
\text { Glyco- } \\
\text { lated }\end{array}$ & & & & \\
\hline \multicolumn{11}{|l|}{ Hole 565} \\
\hline $3-1,111-115$ & 83 & 14 & 3 & 14.52 & 1.502 & 17.21 & - & $5-20$ & upper Pleistocene & \\
\hline $6-2,80-82$ & 89 & 9 & 2 & 13.84 & 1.500 & 17.21 & + & $s-15$ & upper Pleistocene & \\
\hline $11-4,119-121$ & 93 & 6 & i & 14.89 & 1.501 & 17.08 & + & $15-30$ & upper Pliocene & \\
\hline 17-3. $53-55$ & 86 & 10 & 4 & 14.52 & 1.500 & 17.05 & + & 20 & upper Pliocene & \\
\hline $23-5,37-39$ & 89 & 9 & 2 & 15.09 & 1.501 & 17.38 & + & 0 & upper Pliocene & \\
\hline $27-6,130-136$ & 82 & 11 & 7 & 14.82 & 1.504 & 17.14 & + & 0 & upper Pliocene & \\
\hline $30-4,26-28$ & 87 & ii & 2 & 14.69 & 1.500 & 17.05 & + & 0 & lower Pliocene & \\
\hline \multicolumn{11}{|l|}{ Hole 567A } \\
\hline $1-1,33-34$ & 63 & 26 & 11 & 14.94 & 1.497 & 17.28 & - & - & Pliocene & \\
\hline $3-1,43-45$ & 78 & 21 & $i$ & 15.30 & 1.494 & 17.55 & - & - & Pliocene & \\
\hline $4-3,110-112$ & 83 & 15 & 2 & 15.83 & 1.495 & 18.02 & + & 0 & lower Miocene & \\
\hline $7-1,58-60$ & 92 & 4 & 4 & 14.18 & 1.499 & 17.38 & + & 0 & lower Miocene & \\
\hline $9-1,59-60$ & 78 & 19 & 3 & 15.09 & 1.501 & 17.80 & - & 0 & lower Miocene & \\
\hline $14-2,131-133$ & 95 & 3 & 2 & 14.89 & $\begin{array}{l}1.506 \\
1.531\end{array}$ & 16.82 & + & 15 & lower Miocene & $\begin{array}{l}\text { Serpentinitic } \\
\text { mud }\end{array}$ \\
\hline $17 \cdot 1,73-75$ & 84 & 14 & 2 & 14.76 & $\begin{array}{l}1.503 \\
1.533\end{array}$ & 16.88 & ++ & 5 & ? & $\begin{array}{l}\text { Serpentinitic } \\
\text { mud }\end{array}$ \\
\hline $20-1,17-20$ & 54 & 46 & 0 & 14.18 & $\begin{array}{l}1.51 \\
1.535\end{array}$ & 16.98 & +++ & 10 & ? & $\begin{array}{l}\text { Serpentinitic } \\
\text { mud }\end{array}$ \\
\hline Hole 568 & & & & & & & & & & \\
\hline $1-1,80-82$ & 71 & 22 & 7 & 14.24 & 1.501 & 17.14 & - & - & Pleistocene & \\
\hline $3 \cdot 6,87-89$ & 62 & 30 & 8 & 15.02 & 1.497 & 17.84 & - & - & Pleistocene & Tuffaceous \\
\hline $5-7,18-20$ & 42 & 25 & 32 & 13.42 & 1.494 & 17.66 & - & - & Pleistocene & ash-layer \\
\hline $8-3,61-63$ & 69 & 20 & 11 & 14.72 & 1.496 & 17.45 & + & - & Pleistocene & \\
\hline $10-1,97-99$ & 76 & 18 & 6 & 14.77 & $\begin{array}{l}1.496 \\
\end{array}$ & 17.21 & - & - & Pleistocene & \\
\hline $12-5,102-104$ & 75 & 19 & 6 & 14.89 & $\begin{array}{l}1.497 \\
\end{array}$ & 17.59 & - & - & Pleistocene & \\
\hline $17-2,86-88$ & 85 & 14 & $i$ & 15.15 & $\begin{array}{l}1.497 \\
\end{array}$ & 17.31 & + & 0 & $\begin{array}{l}\text { Pliocene } \\
\text { Plo }\end{array}$ & \\
\hline $22-5,50-52$ & 71 & 17 & 12 & 12.99 & $\begin{array}{l}1.497 \\
\end{array}$ & 17.73 & \pm & 0 & $\begin{array}{l}\text { middle Miocene }\end{array}$ & \\
\hline $25-4,55-57$ & 77 & 17 & 6 & 14.79 & 1.496 & 17.08 & + & & $\begin{array}{l}\text { middle Miocene }\end{array}$ & \\
\hline $28-7,31-33$ & 65 & 28 & 7 & 13.84 & 1.496 & 17.05 & - & 0 & & \\
\hline $33-4,87-89$ & 75 & 22 & 3 & 15.41 & 1.500 & 17.57 & + & 3-5 & $\begin{array}{l}\text { middle Miocene } \\
\text { ent }\end{array}$ & \\
\hline $38-6,82-84$ & 83 & 16 & 1 & 15.41 & 1.496 & 17.55 & - & 5 & & \\
\hline $41-4,70-72$ & 72 & 24 & 4 & 15.55 & 1.494 & 17.77 & - & $5-10$ & lower Miocene & \\
\hline $43-2,48-50$ & 72 & 24 & 4 & 15.28 & 1.496 & 17.48 & - & $5-10$ & lower Miocene & \\
\hline $44-3,114-116$ & 69 & 27 & 4 & 15.66 & 1.494 & 17.38 & + & $5-10$ & lower Miocene & \\
\hline Hole 569 & & & & & & & & & & \\
\hline $1-1,104-106$ & 83 & 15 & 2 & 15.15 & 1.496 & 17,38 & + & - & Pleistocene & \\
\hline $2-1,112-114$ & 75 & 21 & 4 & 14.82 & 1.500 & 17.31 & - & - & Pleistocene & \\
\hline $3 C C, 54-56$ & 75 & 17 & 8 & 14.84 & 1.499 & 17.38 & + & - & Pleistocene & Ash layer \\
\hline $6-3,55-57$ & 82 & is & 3 & 15.15 & 1.499 & 17.21 & - & - & Pleistocene & \\
\hline $9-1,9-10$ & 84 & 9 & 7 & 14.84 & 1.501 & 17.38 & - & - & upper Miocene & \\
\hline $12-4,60-62$ & 70 & 28 & 2 & 14.97 & 1.495 & 17.62 & + & - & lower Miocene & \\
\hline $15-2,125-127$ & 89 & 6 & 5 & 14.97 & 1.499 & 17.57 & - & - & lower Miocene & \\
\hline $18-1,136-138$ & 67 & 28 & 5 & 15.07 & 1.498 & 17.48 & - & - & lower Miocene & \\
\hline $23-3,62-64$ & 75 & 20 & 5 & 13.24 & 1.491 & 17.48 & + & 0 & lower Miocene & \\
\hline $27-1,53-55$ & 78 & 17 & 5 & 14.55 & 1.496 & 17.59 & - & 0 & lower Miocene & \\
\hline Hole $569 \mathrm{~A}$ & & & & & & & & & & \\
\hline $2-2,1-2$ & 56 & 33 & 11 & 14.64 & 1.495 & 17,38 & - & 0 & upper Oligocene & Ash layer \\
\hline $4-2,65-67$ & 71 & 24 & 5 & 15.22 & 1.496 & 17,73 & + & $3-5$ & upper Oligocene & \\
\hline $6-1,54-56$ & 87 & 10 & 3 & 14.79 & 1.498 & 17.55 & + & $5-10$ & upper Oligocene & \\
\hline $9-2,0-2$ & 96 & 3 & i & 15.20 & 1.494 & 17.28 & + & 10 & upper Eocene & \\
\hline Hole 570 & & & & & & & & & & \\
\hline $1-4,6-8$ & 65 & 22 & 13 & 14.89 & 1.495 & 17,31 & _- & - & Pleistocene & Tuffaceous \\
\hline $4-3,12-14$ & 58 & 40 & 2 & $\begin{array}{l}14.89 \\
14.89\end{array}$ & $\begin{array}{l}1.499 \\
1.499\end{array}$ & 17.45 & + & $=$ & Pleistocene & Tuffaceous \\
\hline $9 \cdot 1,30-32$ & 73 & 23 & 4 & 14.89 & 1.500 & 17.38 & + & - & Pleistocene & \\
\hline $14-6,14-16$ & 72 & 24 & 4 & $\begin{array}{l}15.15 \\
15.15\end{array}$ & 1.496 & $\begin{array}{l}1.38 \\
17.29\end{array}$ & \pm & $=$ & Pleistocene & \\
\hline $17-2,64-66$ & 74 & 20 & 6 & 15.04 & 1.500 & 17.60 & - & - & Pleistocene & \\
\hline $18-1,23-25$ & 70 & 27 & 3 & 15.55 & 1.496 & 17.90 & - & - & Pleistocene & \\
\hline $19-2,76-78$ & 68 & 22 & 10 & 15.07 & 1.498 & 17.62 & - & - & Pleistocene & $\begin{array}{l}\text { Authigenic } \\
\text { dolomite }\end{array}$ \\
\hline $22-3,64-66$ & 82 & 13 & 5 & 15.28 & 1.496 & 17.38 & + & - & Pleistocene & \\
\hline $23-4,30-32$ & 62 & 30 & 8 & 14.77 & 1.498 & 17.21 & - & - & Pleistocene & \\
\hline $25-3,60-62$ & 78 & 14 & 8 & 15.07 & 1.499 & 17.28 & - & - & $\begin{array}{l}\text { Pliocene } \\
\text { Plo }\end{array}$ & \\
\hline $29-2,74-76$ & 72 & is & 13 & 14.60 & 1.499 & 17.22 & - & 0 & upper Miocene & \\
\hline $32-4,114-116$ & 59 & 22 & 19 & 14.77 & 1.499 & 17.21 & - & 0 & upper Miocene & Tuffaceous \\
\hline $34-2,114-116$ & 81 & 11 & 8 & 14.64 & 1.499 & 17.38 & + & $15-20$ & & \\
\hline $36-1,118-120$ & 88 & 7 & 5 & 14.70 & & 17.40 & - & $15-20$ & early Eocene & \\
\hline $38-1,107-109$ & 90 & 4 & 6 & 14.48 & 1.502 & 17.21 & + & $20-30$ & early Eocene & \\
\hline $38-1,132-134$ & 96 & 3 & 1 & 15.28 & 1.502 & 17.34 & ++ & $30-35$ & early Eocene & \\
\hline $39-1,136-138$ & 91 & 7 & 2 & 13.95 & 1.502 & 16.72 & ++ & $20-22$ & early Eocene & $\begin{array}{l}10 \mathrm{~m} \text { above } \\
\text { serpentinitic } \\
\text { basement }\end{array}$ \\
\hline
\end{tabular}

Note: In Chlorite column, $-=$ no chlorite; $+=$ chlorite identified after heating to $500^{\circ} \mathrm{C}$ by d -001 or $\mathrm{d}-002 ;++=$ chlorite identified by $\mathrm{d}-003$ in untreat ed samples: $+++=$ chlorite is the main 7-A mineral. The label "serpentinitic mud" implies that the composition of the 7-A clay mineral includes serpentine and chlorite and that several trioctahedral minerals occur in these samples.

The Nonexpandable layers $(\%)$ column refers to the percentage of illite layers in the montmorillonites and the following values are given: - indicates that no (002) and (003) d-spacings are developed; 0 means that $d$-spacings $(002)$ and $(003)$ indicate lack of nonexpandable layers; percentage of nonexpandable layers was calculated according to Reynolds and Hower (1970) and Brindley and Brown (1980), for example, 3-5 means 3 to 5\% nonexpandable layers in the smectite. 
Holes 569, 569A

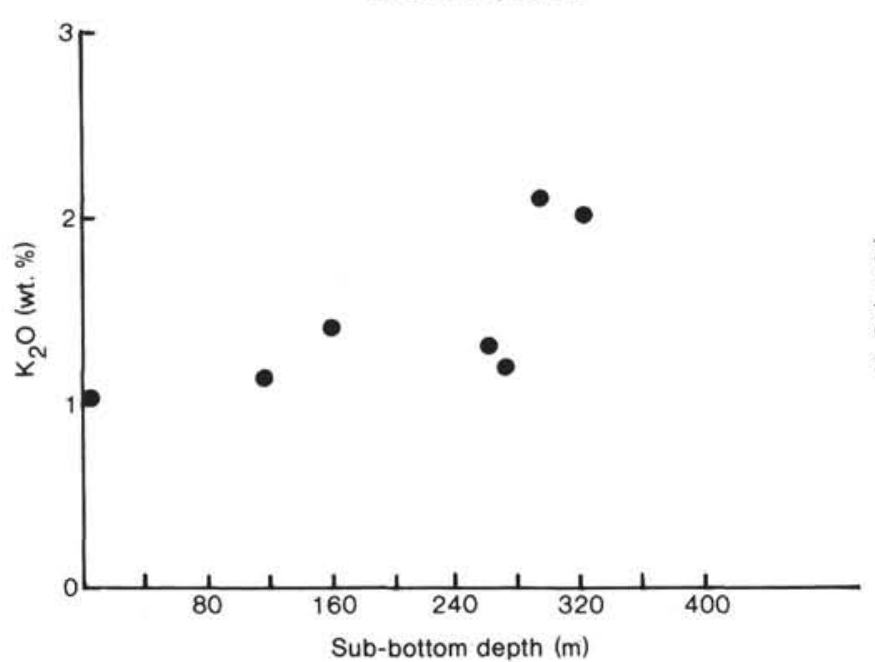

Hole 570

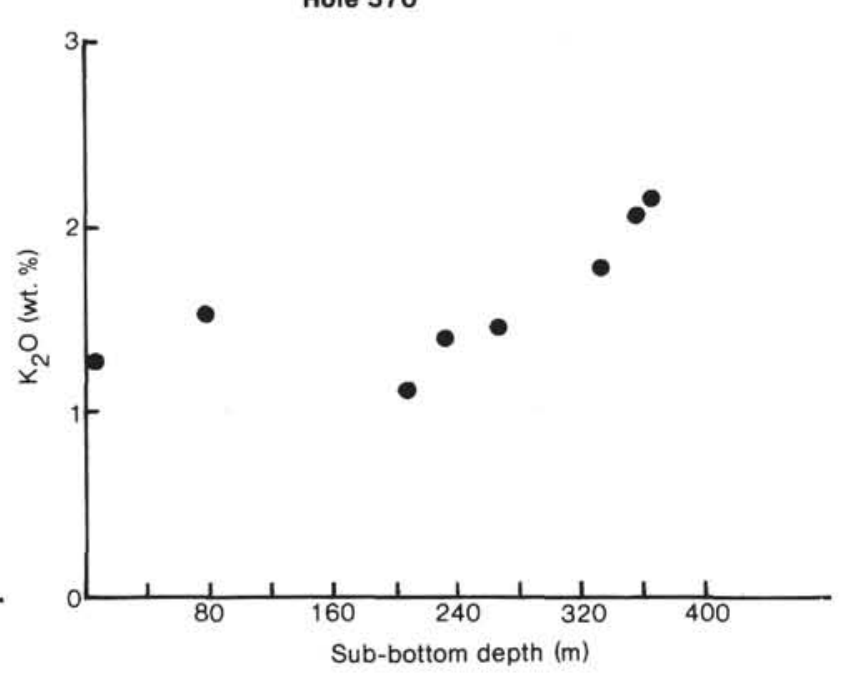

Figure 9. $\mathrm{K}_{2} \mathrm{O}$ content of the $<2-\mu \mathrm{m}$ fraction versus sub-bottom depth $(\mathrm{m})$ diagram for Holes 569, 569A, and 570 .

An increasing development of this $10-\AA$ structure toward older sediments is shown in a $10-\AA$ index versus sediment age diagram (Fig. 13).

DTA (differential thermal analysis) investigations showed that the loss of interlayer and adsorbed water starts at about $100^{\circ} \mathrm{C}$, and the maximum of this endothermic reaction occurs at 330 to $350^{\circ}$. The DTA curves of the $<2-\mu \mathrm{m}$ samples exhibit the characteristic patterns for smectites, as shown by MacKenzie (1957). There are no important changes recognizable in the development of DTA curves with increasing sediment age.

The infrared spectra of the $<2-\mu \mathrm{m}$ fraction of Pleistocene-Miocene samples show the $\mathrm{O}-\mathrm{H}$ stretching vibration at $3620 \mathrm{~cm}^{-1}, 3700 \mathrm{~cm}^{-1}$, and $3400 \mathrm{~cm}^{-1}$ (Fig. 14). Only the latter can be attributed to smectite; the others belong to kaolinite. Oligocene and Eocene $<2-\mu \mathrm{m}$ samples lack these $\mathrm{O}-\mathrm{H}$ bands. The absorption band assigned to the $\mathrm{H}-\mathrm{O}-\mathrm{Al}$ band at $935 \mathrm{~cm}^{-1}$ becomes less distinctly resolved from the main $\mathrm{Si}-\mathrm{O}$ band with increasing age of the sediments (Fig. 15). The calculation of saturation indexes for four smectites (beidellite, montmorillonite Aberdeen, montmorillonite Belle Fourche, and Ca-montmorillonite) yielded high to very high oversaturation of the pore fluids $\left(10^{5}-10^{9}\right.$ times); the chemical composition of smectite in the slope sediments as established by chemical analyses and XRD is similar to the composition of beidellite.

The (001) peak of kaolinite has been found in almost every clay fraction. The mineral shows a broad reflection from 7.13 to $7.25 \AA$. Other d-spacings of kaolinite were not observed. The kaolinite amount decreases with depth in the sediments of Holes 569A and 570 (Table 5). This was also confirmed by a lack of the kaolinite $\mathrm{O}-\mathrm{H}$ bands at $3620 \mathrm{~cm}^{-1}$ and $3700 \mathrm{~cm}^{-1}$ in the infrared spectra of Oligocene and Eocene sediments.

Small quantities of chlorite were identified (Table 5). The chlorite content was well below the detection limit of infrared spectroscopy. In sediments containing serpentinitic muds, moderately high amounts of Mg-chlorite were recognized (Table 5).

\section{DISCUSSION}

\section{Primary Composition}

The correlation between quartz, calcite, and plagioclase indicates that these minerals were transported jointly, for instance, in turbidity currents or suspension clouds. They are interbedded with volcanic ash layers. Quartz and plagioclase are mainly transported in aqueous suspensions, in which plagioclase is predominant by a factor of about 5 . In ash layers, however, the quartz/plagioclase ratio is about $1: 1$, indicating a different rock source compared to the material derived from suspension clouds or turbidites. The rhyolitic composition of the ash layers is also consistent with this assumption. The average composition of the Leg 84 detrital plagioclase in the average slope sediments is consistent with the andesitic source rock in the coast range of Guatemala and Costa Rica. Albite and labradorite in the basal section at Site 567 can be explained by the occurrence of ophiolitic igneous rock detiitus in these samples. The difference between the "andesitic" minerals (plagioclase, amphiboles, and pyroxenes) and the relative acidic composition of the plutonic ash layers can be explained by the occurrence of andesitic rocks and rhyolitic volcanoes on land.

The distribution pattern of heavy minerals is consistent with the andesitic rock source on land. In the sediments of sites where ophiolitic rocks were drilled, additional accessory minerals occur; this fact is also confirmed by the bulk chemistry of the sediments of Holes $567,569,569 \mathrm{~A}$, and 570, which have enriched $\mathrm{Cr}$ and $\mathrm{Ni}$ contents. Accessory minerals like rutile, ilmenite, sphene, and zircon control the amounts of $\mathrm{TiO}_{2}$ and $\mathrm{Zr}$. According to Pearce and Cann (1973), these relatively immobile elements can be used to classify igneous rocks and therefore can indicate the source rocks of sediments. The $\mathrm{TiO}_{2}-(\mathrm{Zr}+\mathrm{Y})-(\mathrm{Cr}+\mathrm{Ni})$ diagram (Fig. 5) indicates relatively low differences in the chemistry of source rocks by rather constant $\mathrm{TiO}_{2} /(\mathrm{Zr}+\mathrm{Y})$ ratios (Fig. 5). The influence of serpentinitic detritus is indi- 

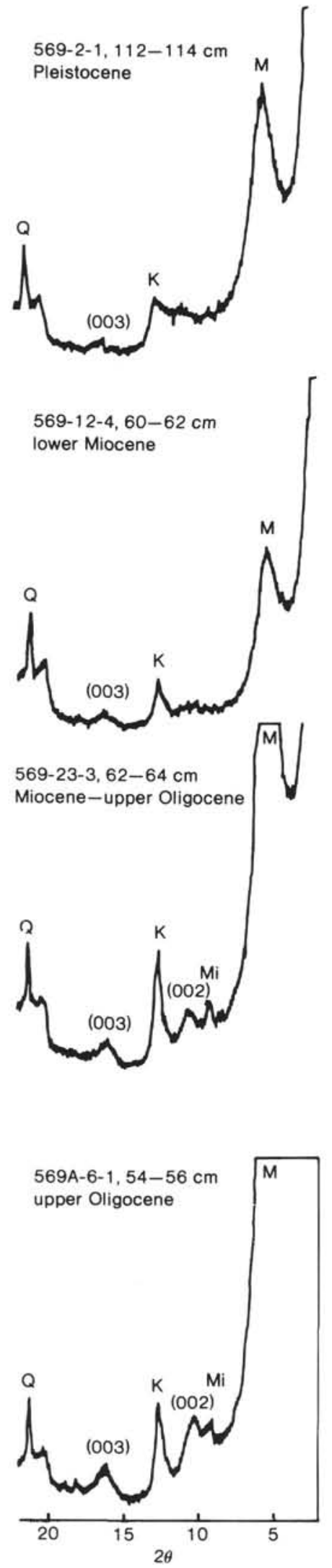

Figure 10. Increase of smectite (001), (002), and (003) peak amplitudes with increasing age in the glycolated samples $(<2 \mu \mathrm{m}) . \mathrm{Q}, \mathrm{M}, \mathrm{Mi}$, and $\mathrm{K}$ refer to quartz, montmorillonite, illite, and kaolinite, respectively. cated by a trend toward the $\mathrm{Cr}+\mathrm{Ni}$ pole. The different position of the Site 565 sediments on this figure can be attributed to a slightly different chemistry of the source rocks on land in Costa Rica. The different position of sediments compared to ash layers in the $\mathrm{Zr}-\mathrm{Y}-\mathrm{TiO}_{2}$ diagram elucidates the predominance of a rhyolitic composition in pure ash layers and andesitic composition in the muds. The content of mafic components like amphiboles, pyroxenes, and other accessories is shown by a trend toward the $\mathrm{TiO}_{2}$ pole.

A sediment of great interest is the Cretaceous limestone drilled in Core 19 of Site 567. The appearance of pelagic fossils, clinoptilolite, chalcedony, and a high manganese content is a characteristic feature of deep-water limestones covering Mesozoic ophiolite complexes (Coleman, 1977). It is therefore suggested that this sediment belongs to the ophiolite sequence.

\section{DIAGENESIS}

\section{Clastic Minerals}

The interstitial waters of the Leg 84 slope sediments are oversaturated 5 to 30 times with quartz. Accordingly, etching of quartz grains was not observed. The lack of authigenic quartz cement is consistent with the low grade of diagenesis observed in the slope sediments off Guatemala and Costa Rica.

Saturation calculations yielded distinct oversaturation for albite or intermediate plagioclase. Accordingly, under the electron microscope no corrosion of albite as well as andesine and oligoclase (Plate 3, Fig. 2.) was visible in the soft sediments.

\section{Biogenic Silica}

The measured refraction indexes of sponge spicules (Table 3) are higher than the figures published by Hurd and Theyer (1975). Nevertheless, the refraction index is still in their opal-A range. According to Hurd and Theyer (1975), the slight increase of the refractive index of the sponge spicules studied can be related to a water loss of about $1 \mathrm{wt}$. $\%$ with increasing sediment age (Table 3). There seems to be, however, no perfect correlation between the increase of refraction index and the sediment age. This is also confirmed by the occurrence of opal-A and chalcedony side by side in early Eocene sediments. The preservation of opal-A in Sample 570-37-1, 15-20 $\mathrm{cm}$ can be the result of thicker tests and an embedding of these tests in a clay-rich groundmass. The latter impedes silica diagenesis, according to Kastner et al. (1977). Chalcedony occurs where the total carbonate content is higher; this environment triggers silica diagenesis (570$38-1,50-52 \mathrm{~cm}$ ).

The observation of dissolution pits (569A-9-2, 0-2 cm) (Plate 3, Fig. 3.) is in good agreement with the calculated saturation patterns of amorphous silica showing an increasing undersaturation towards the deepest sediment sections.

The formation of chalcedony in Eocene sediments can be explained by a pore-water undersaturation of opalCT (cristobalite) and oversaturation for quartz and chalcedony. This is indicated by the trend of pore-water 

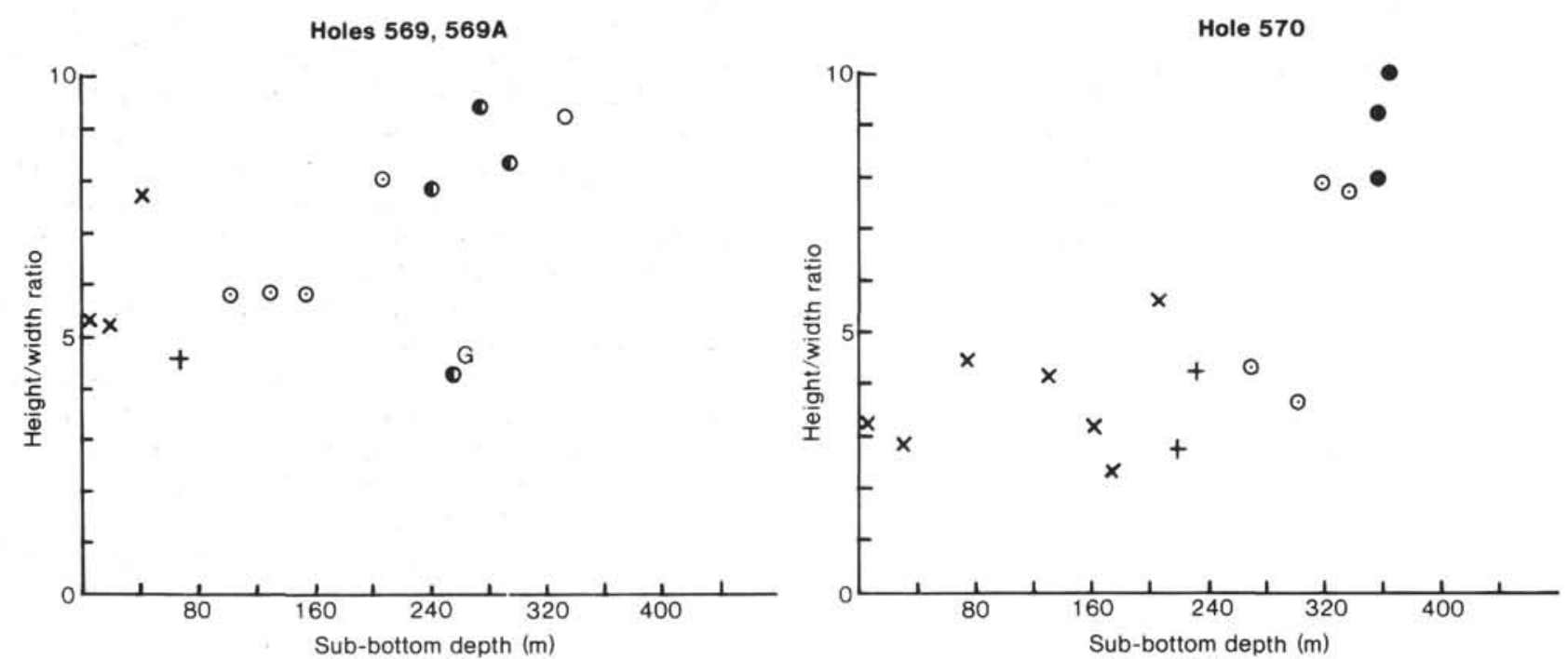

Figure 11. Height/width ratio-sub-bottom depth diagram for glycolated (001) samples of montmorillonite in the $<2-\mu \mathrm{m}$ fraction, Holes $569,569 \mathrm{~A}$, and $570 . \mathrm{G}=$ ash layer. $=$ Eocene; $=$ Oligocene; $\odot=$ Miocene; $+=$ Pliocene; and $\times=$ Pleistocene

composition in the soft sediments. Although it can be suggested that the pore waters in these consolidated sediments were more highly oversaturated with respect to quartz than to chalcedony, the latter is precipitated first because of the Ostwald rule. Therefore, chalcedony was formed by dissolution of opal-A in these Eocene sediments. However, if the low geothermal gradient off Guatemala (see site reports) is taken into consideration, the occurrence of chalcedony is surprising. Bulk composition of the sediment seems to be the most important factor in $\mathrm{SiO}_{2}$ diagenesis. Nevertheless, the distribution of $\mathrm{SiO}_{2}$ minerals in the Leg 84 sediments is in agreement with the distribution pattern of opal-A and its successors in geologic times, as established by Riech and von $\operatorname{Rad}$ (1979).

\section{Carbonates}

The calculated low $\mathrm{Sr} / \mathrm{Ca}$ ratios of the solution in equilibrium with calcite, dolomite, and aragonite in the samples suggest that these carbonates were formed in contact with seawater rather than with the deep interstitial water, in which the $\mathrm{Sr} / \mathrm{Ca}$ ratio is higher than in seawater.

A further indication of an equilibration of the carbonates with surface seawater rather than with interstitial water is the high manganese content of the carbonates investigated.

The formation of dolomite and aragonite in the serpentinite samples can be explained by a pore water or seawater-serpentinite reaction. However, it is not clear whether the dolomite in the serpentinitic material of Holes 566 and $566 \mathrm{C}$ was formed by direct precipitation or by replacement of calcite or aragonite.

Pisciotto and Mahoney (1981) explained the formation of isolated rhombohedral dolomite crystals in unconsolidated sediments off southern California and Baja California by a decay of organic matter. These dolomites were formed as precipitates in shallow subsurface zones of high alkalinity provided by abundant $\mathrm{CO}_{2}$ and methane production during microbial decay of organic matter. A similar explanation of isolated dolomite rhombs and micritic dolomite cement in the sediments of the Gulf of California was presented by Kelts and McKenzie (1982).

Indeed, high rates of alkalinity (up to $118 \mathrm{meq} / \mathrm{L}$ ) and high concentrations of methane are reported for the interstitial waters off Guatemala (see site reports), which contributed to the formation of gas hydrates (Kvenvolden, this volume). Electron microscope investigations of the dolomite crystals (Plate 3, Fig. 4) indicate an authigenic formation. A relatively high alkalinity $(40 \mathrm{meq} / \mathrm{L})$ is found in the pore water of Sample 570-19-2, 76-78 $\mathrm{cm}$, so that the dolomite formation can probably be attributed to the decay of organic matter. Formation of these rhombs presumable can be related to the dolomitization of silt-sized calcite crystals or perhaps direct precipitation.

The appearance of the micritic dolomite (570-27-1, $10-12 \mathrm{~cm}$ ) may also be related to the decay of organic matter. The occurrence of a 3- to 4-m-thick gas hydrate layer indicates an unusually large amount of hydrocarbon in this sediment section. Therefore, a mode of formation similar to the dolomite in Sample 570-19-2, 76$78 \mathrm{~cm}$ may be possible. It is suggested that this dolomite was formed by dolomitization of calcareous ooze.

Davies and Supko (1973) presume that a magnesium enrichment related to igneous activity is responsible for the formation of isolated dolomite crystals. The weathered serpentinites at the base of Hole 570 can provide this magnesium source but it is unlikely that this is reasonable for the dolomites, because no dolomite was detected in the sediment column between Sections 570-27-1 (dolomite layer) and 570-39, CC (first serpentinite occurrence).

The formation of dolomite in the sediments investigated is favored by the patterns of interstitial pore-water chemistry: high $\mathrm{pH}(\sim 8.5)$ and unusually large alkalinities $(118 \mathrm{meq} / \mathrm{L})$ in some of the pore waters provide higher concentrations of $\mathrm{CO}_{3}^{--}$than in average seawater, where the dolomite precipitation is impeded for ki- 


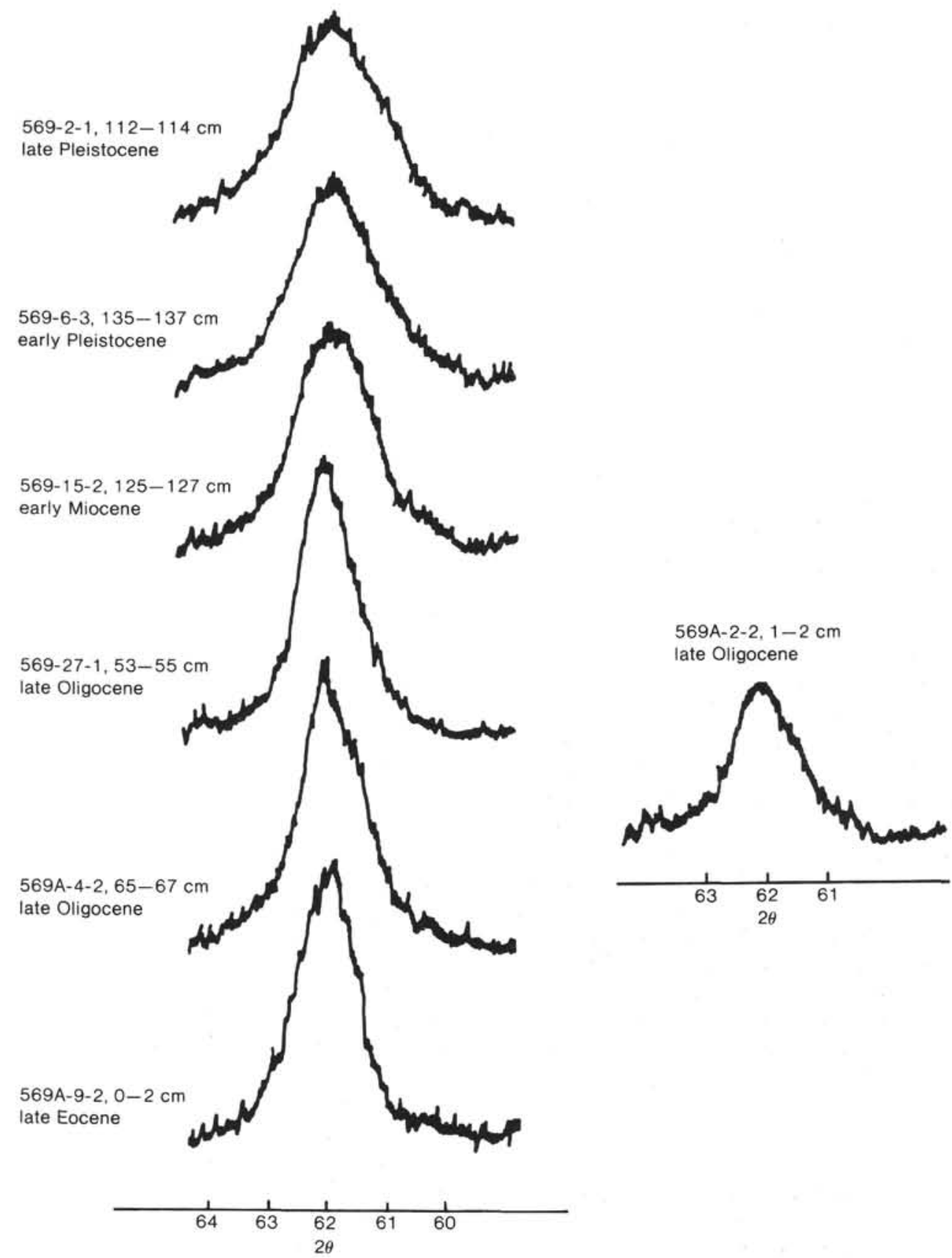

Figure 12. Diffractograms of (060), montmorillonite, in the nonoriented $<2-\mu \mathrm{m}$ fraction. Sample 569A-2$2,1-2 \mathrm{~cm}$ is an Oligocene ash layer.

netic reasons. Under the present conditions of high oversaturation (100-1000 times), however, the dolomitization of calcite is strongly favored. According to Lippmann (1973), the activity of $\mathrm{CO}_{3}^{-}-$is the most important factor for dolomite formation. It may be possible that the unusually high $\mathrm{CO}_{3}^{--}$concentrations in some of the interstitial waters provided a direct precipitation of dolomite (isolated dolomite rhombs, 570-19-2, 76-78 cm). According to Kastner (1983), dolomitization of calcite and aragonite is strongly inhibited by sulfate concentrations of approximately 5 to $7 \%$ of the seawater value. In some of the interstitial waters of Leg 84 (568-6-4, 0.7 $\mathrm{mM} \mathrm{SO}{ }_{4}^{-} ; 568-12-3,0.6 \mathrm{mM} \mathrm{SO}_{4}^{-}$; 570-25-3, 0.9
$\mathrm{mM} \mathrm{SO}_{4}^{--}$; and 570-20-1, $1.0 \mathrm{mM} \mathrm{SO}_{4}^{--}$), the $\mathrm{SO}_{4}^{--}$ concentrations are well below this limit, and therefore dolomitization or at least precipitation of dolomite seems to have been possible.

\section{Accessory Minerals}

Pyrite shows the characteristic evolution from irregular blebs to cubic crystals with increasing diagenesis. The etching of unstable mafic minerals is consistent with the calculated undersaturation of these minerals in the interstitial waters. The occurrence of gypsum in Sample $569 \mathrm{~A}-10-1,0-2 \mathrm{~cm}$ is the result of pyrite alteration in this nodule. The absence of gypsum in the average mud, 
Holes 569, 569A

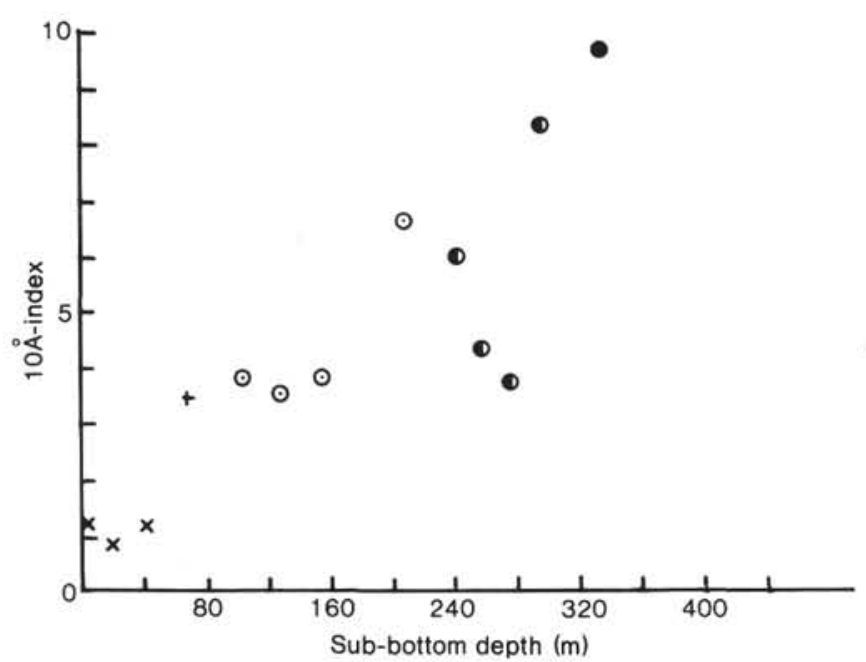

Hole 570

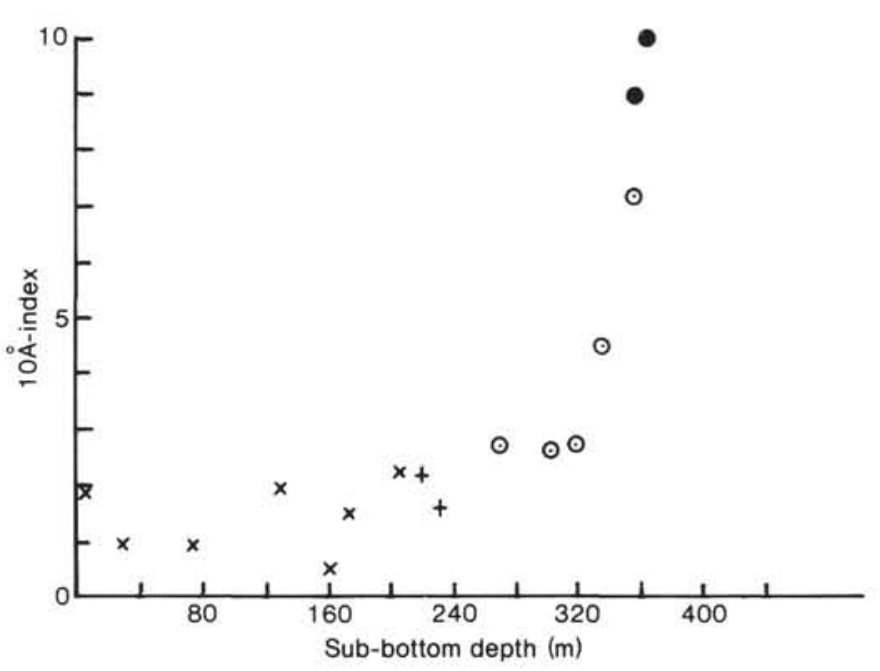

Figure 13. "10- $\AA$ index" versus sub-bottom depth diagram of $<2-\mu \mathrm{m}$ fraction samples after heating to $500^{\circ} \mathrm{C}$. For an explanation of symbols see Figure 11.

however, is consistent with the calculated undersaturation of this mineral in the interstitial waters.

The distribution of phosphate in the pore waters of the slope sediments off Guatemala has been determined by Harrison et al. (1982) from Leg 67 samples: the $\mathrm{PO}_{4}{ }^{3-}$ concentration decreases with increasing depth from about $0.2 \mathrm{mM}$ to values about $0.005 \mathrm{mM}$. This dramatic drop in $\mathrm{PO}_{4}{ }^{3-}$ concentration indicates phosphate precipitation, which indeed is well documented by the abundance of phosphorite micronodules. According to Manheim and Gulbrandsen (1979), apatite is precipitated if the pore waters are oversaturated with apatite, and the obstruction against precipitation can be overcome by the use and replacement of small calcite crystals as nucleation sites. Both conditions for apatite formation are also present in the slope sediments off Guatemala.

\section{Volcanic Glass}

The infrared spectroscopy did not reveal any in-situ alteration of glass shards. Because of the unchanged position of $\mathrm{Si}-\mathrm{O}$ and $\mathrm{Si}-\mathrm{O}-\mathrm{Si}$ bands in the infrared spectra of glass samples investigated, an uptake of alkali elements can also be excluded. Thus no mineralogical and chemical change can be observed during the diagenesis of the rhyolitic glass shards investigated. The strong increase of dissolution pits with sediment age seems to be the only diagenetic process. It indicates an increasing undersaturation of vitreous glass in the interstitial waters of the slope sediments. This undersaturation could not be verified, because glasses of similar composition were not available for the WATEQ program, though pure silica glass would be oversaturated in the upper layers and undersaturated in the lower layers of the sequence, according to WATEQ calculations. An alternative explanation may be the overcoming of kinetic dissolution inhibition in the older sediments.

The importance of kinetics seems to be indicated by the fact that etched glass shards are more frequent in the average mud than in pure ash layers. This may indicate that some components of the average mud, clay minerals, or carbonates are instrumental in the dissolution. It is suggested that the so-called "diagenetic potential" (Schlanger and Douglas, 1974) of volcanic glass becomes effective in clayey or calcareous sediments only. The lack of zeolites in pure ash layers and the low crystallinity of clay minerals (see clay mineral section) supports the idea of an impeded diagenesis in pure ash layers.

\section{Zeolites}

The mode of clinoptilolite occurrence in the bottom sediments of Holes 569, 569A, and 570 suggests an authigenic formation. According to Cosgrove and Papavassiliou (1979), the formation of clinoptilolite in deep sea sediments from smectite and kaolinite can be explained by a reaction of these clay minerals with dissolved species of the interstitial waters. The proposed reaction would be $(\mathrm{Na}, \mathrm{K})$-smectite $+\mathrm{Na}^{+}, \mathrm{K}^{+}+\mathrm{H}_{4} \mathrm{SiO}_{4} \rightarrow$ $(\mathrm{Na}, \mathrm{K})$-clinoptilolite $+\mathrm{H}^{+}+\mathrm{H}_{2} \mathrm{O}$ or kaolinite + $\mathrm{Na}^{+}, \mathrm{K}^{+} \mathrm{H}_{4} \mathrm{SiO}_{4} \rightarrow\left(\mathrm{Na}, \mathrm{K}\right.$ )-clinoptilolite $+\mathrm{H}^{+}+$ $\mathrm{H}_{2} \mathrm{O}$, respectively. The formation of clinoptilolite from smectite is confirmed by a replacement of the smectite groundmass by clinoptilolite in the consolidated basal sediments of Site 570 . The high clinoptilolite content in the basal sediments of Holes 569 and 569A corresponds to a decrease of kaolinite (Table 5). Therefore, the formation of clinoptilolite at the expense of kaolinite is tentatively suggested. Although all interstitial waters all in the stability field of clinoptilolite, a neoformation of clinoptilolite can be observed only in Oligocene-Eocene sediments. This indicates a kinetic inhibition of clinoptilolite formation.

The occurrence of clinoptilolite corresponds well to the geological environment, because according to Mariner and Surdam (1970), clinoptilolite is formed instead of phillipsite in geological environments, with volcanic rocks having a high $\mathrm{Si} / \mathrm{Al}$ ratio and high sedimentation rates. 


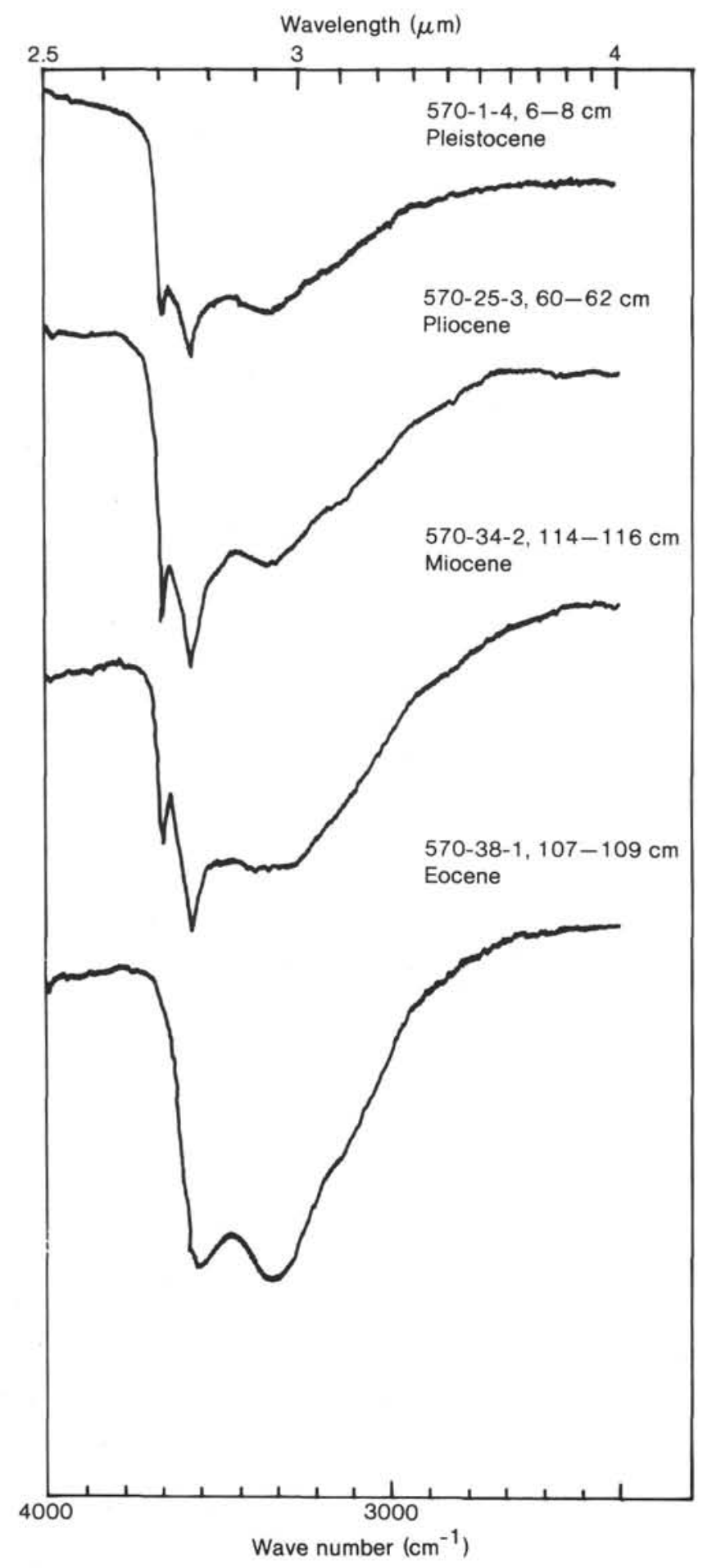

Figure 14. Change of $\mathrm{O}-\mathrm{H}$ bands in infrared spectra of Hole $570<2$ $\mu \mathrm{m}$ fractions with increasing sediment age.
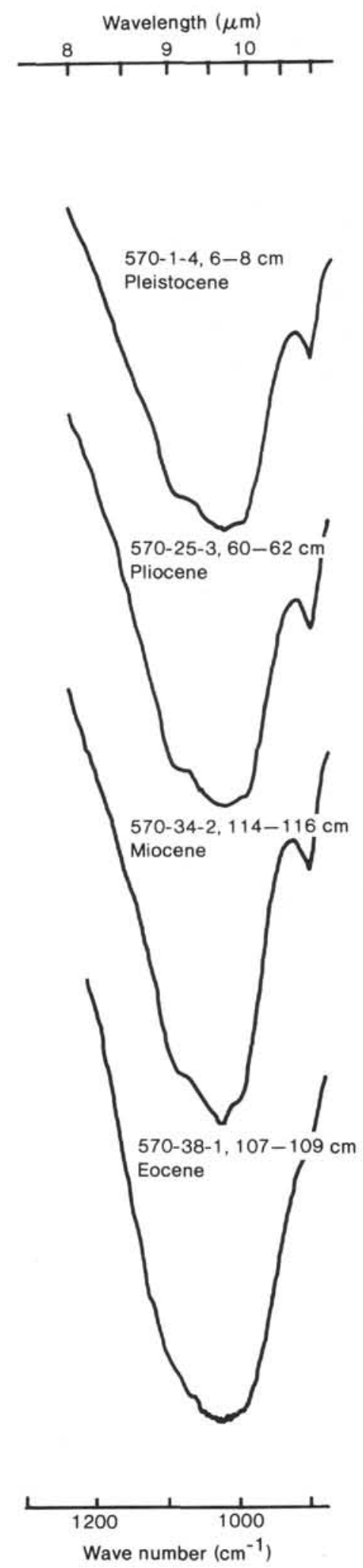

Figure 15. Change of infrared $\mathrm{H}-\mathrm{O}-\mathrm{Al}$ bands of $<2-\mu \mathrm{m}$ fraction with increasing sediment age at Site 570 . 
Alternatively, the absence of phillipsite may be due to the paucity of basaltic glass, which is an important precursor of phillipsite (Boles and Wise, 1978).

Except for evaporites, analcime is related to late-diagenetic or even low-grade metamorphic terrains, where it forms pseudomorphs after heulandite-clinoptilolite group zeolites (Boles, 1981). The occurrence of analcime in the slope sediments is therefore unexpected because of the low geothermal gradients off Middle America (see site reports). A formation of analcime from clinoptilolite is favored by increasing $\mathrm{Na}^{+} / \mathrm{H}^{+}$ratios (Boles, 1971). The proposed reaction is $\mathrm{Na}^{+}+$clinoptilolite $\rightarrow$ analcime $+\mathrm{K}^{+}+\mathrm{SiO}_{2}+\mathrm{H}_{2} \mathrm{O}$. An increase of $\mathrm{pH}$ and of the $\mathrm{Na}^{+} / \mathrm{H}^{+}$ratio during diagenesis can be assumed for the sediments in which analcime occurs. This increase of $\mathrm{pH}$ was probably the result of the $\mathrm{NH}_{4}$ production related to the decay of organic matter. Moreover, in sediment sections next to serpentinites (basal sediments at Site 570), submarine weathering of serpentine minerals caused an increase of $\mathrm{pH}$, which initiated the formation of analcime from clinoptilolite. (All pore waters are oversaturated for analcime.)

The reasons for the occurrence of heulandite in the slope sediments off Costa Rica are unknown. There are no important differences in the bulk chemistry (Table 2), composition of volcanic glass (Table 4), or interstitial water composition (J. Lebel, personal communication, 1983) between these sediments and those off Guatemala.

However, an inverse trend of clay-mineral diagenesis in these sediments (see clay section) suggests reworking of material with higher maturity at the slope offshore Costa Rica. This may be relevant to the occurrences of heulandite and analcime in these sediments.

Hydrous Ca-silicates like gyrolite are formed during the serpentinization of ultrabasic rocks by a Ca-metasomatism in the adjacent rocks. This process is called rodingitization and is related to temperatures of 100 to $400^{\circ} \mathrm{C}$ (Honnorez and Kirst, 1975). Gyrolite was synthesized by Buckner et al. (1960) at temperatures of about $300^{\circ} \mathrm{C}$. This fact indicates that the gyrolite in the sediment overlying the serpentinitic basement at Site 570 (570$39, \mathrm{CC}$ ) was formed in a thermic environment different from the present trench-slope environment.

\section{Clay Minerals}

An authigenic formation of the smectites was suggested by Heinemann and Füchtbauer (1982) because of the occurrence of fibrous and in part spheroidal growth forms. Compared with the distribution in the silt fraction, the smectite amount in the clay fraction is nearly constant (about 70-80\%) and increases in sediments older than Miocene ( $>90 \%$ ), which may suggest an authigenic formation of smectite. Further evidence is its texture in smear slides and under the electron microscope (Plate 3, Figs. 1 and Plate 3, Fig. 3): the clay minerals filling veins in brittle-ductile shear zones (Helm and Vollbrecht, this volume) and clay-mineral fillings of radiolarian and foraminifer tests differ markedly from those in the surrounding sediment; they are coarser in the veins and tests, indicating accretion. Replacement of plagioclase and mafic accessory minerals by smectite also proves its authigenic formation. Kaolinite and chlorite in the slope sediments are presumably detrital, as suggested by Heinemann and Füchtbauer (1982). The occurrence of serpentine and chlorite in the lower sediment section at Site 567 has to be related to serpentinitic mud admixtures. Trioctahedral smectite presumably was formed authigenically in the latter sediments (Helm, this volume).

(Na, K)-clinoptilolite is the thermodynamically stable phase with respect to the pore fluids investigated. So the apparent authigenic formation of smectite in the Leg 84 slope sediments seems to be in contradiction to these calculations.

However, smectite can be explained as a metastable formation instead of clinoptilolite. Clinoptilolite was formed at the expense of smectite only in early Eocene sediments. The metastable formation of smectite is triggered by its high oversaturation in the interstitial waters and by the availability of smectite nucleation sites of detrital smectite. On the other hand, smectite was suggested to be thermodynamically stable at the sediment/seawater interface by Helgeson et al. (1969).

The most important observation concerning clay-mineral diagenesis is the increase of crystallinity of montmorillonite with increasing sediment age shown by the $\mathrm{X}$-ray diffraction patterns. The increasing amplitude and height/width ratio of the (001) spacings of montmorillonite indicate an increasing ordering of the lattice in the (001) direction. As shown at Site 570, this increase of crystallinity is controlled by age rather than by depth of burial. Increasing height/width ratios of $(060)$ d-spacings of montmorillonites toward older sediments show that there is also an increasing ordering in the b-direction. This increase of $(060)$ height/width ratio cannot be related to a change of octahedral charge, as shown by the unchanged d-spacings (060) (Table 5). The increase of the $10-\AA$ peak with sediment age also indicates an increasing crystallinity of montmorillonite. This feature is also controlled by sediment age rather than by burial depth.

A conversion of smectite to illite through a mixedlayer illite-smectite series is a characteristic trend in diagenesis (Hoffman and Hower, 1979). The first stages of such a transformation can be recognized in the slope sediments by the occurrence of random illite-smectite mixed layers in Oligocene and early Eocene sediments of Holes 569A and 570. In view of the low geothermal gradient, the occurrence of illite-smectite mixed layers may be surprising, but time seems to be an important factor and the occurrence of illite-smectite mixed layers with relatively high amounts of illite may be explained by the Eocene age of these sediments.

Site 565 off Costa Rica is exceptional, because the highest crystallinity and percentage of nonexpandable layers is found in the smectites of the upper part of the sequence. It is suggested that these are detrital smectites that were already supplied in their present stage of maturity. Such a supply of terrigenous matter perhaps can also explain the occurrence of heulandite and analcime in these Pleistocene to Pliocene sediments.

The increasing portion of illite-type layers in the smectites was also confirmed by the infrared spectroscopy studies. The $\mathrm{O}-\mathrm{H}$ infrared bands of the Oligocene and 
Table 6. Sequence of digenesis determined in the slope sediments off Guatemala.

\begin{tabular}{|c|c|c|c|c|c|c|c|c|c|c|c|}
\hline Age & $\begin{array}{l}\text { HWR } \\
(060)\end{array}$ & $\begin{array}{l}\text { HWR } \\
(001) \\
\text { Gly. }\end{array}$ & $\begin{array}{c}10-\mathrm{A} \\
\text { index } \\
\left(500^{\circ} \mathrm{C}\right)\end{array}$ & $\begin{array}{c}(003) \\
Q z \\
(100)\end{array}$ & $\begin{array}{c}\text { Illite } \\
\text { layers }(\%)\end{array}$ & $\underset{\left(\mathrm{cm}^{-1}\right)}{\mathrm{IR}}$ & Opal & Pyrite & $\begin{array}{c}\text { Carbo- } \\
\text { nates }\end{array}$ & $\begin{array}{c}\text { Mafic } \\
\text { accessory } \\
\text { minerals }\end{array}$ & Zeolites \\
\hline $\begin{array}{l}\text { Pleistocene } \\
\text { and younger }\end{array}$ & 1.6 & 5.1 & 5.4 & 0.2 & 0 & & Opal-A & $\begin{array}{l}\text { Irregular } \\
\text { blebs }\end{array}$ & $\begin{array}{l}\text { Dolomite } \\
\text { rhombs }\end{array}$ & & \\
\hline Pliocene & 1.9 & 5.0 & 6.8 & 0.4 & 0 & & Opal-A & & $\begin{array}{l}\text { Dolomite } \\
\text { layer }\end{array}$ & & $\begin{array}{l}\text { Occasionally } \\
\text { clinoptilolite }\end{array}$ \\
\hline Miocene & 2.9 & 8.0 & 8.1 & 0.8 & 3 & & $\begin{array}{l}\text { Opal-A } \\
\text { etched }\end{array}$ & & & Increase of etching & (? detrital) \\
\hline Oligocene & 3.4 & 8.5 & 10.6 & 1.0 & 4.4 & & $\begin{array}{l}\text { Opal-A } \\
\text { etched }\end{array}$ & $\begin{array}{l}\text { Filling of skeletons, } \\
\text { framboids }\end{array}$ & & & Clinoptilolite \\
\hline Eocene & 3.7 & 9.8 & 12 & 2.3 & 21 & $\begin{array}{l}\text { Lack } \\
\text { of } \\
3620 \text {, } \\
3700 \text {, } \\
\text { and } \\
935\end{array}$ & $\begin{array}{c}\text { (Opal-A) } \\
\text { (Opal-CT) } \\
\text { Chalce- } \\
\text { dony }\end{array}$ & $\begin{array}{l}\text { Cubic } \\
\text { Crystals }\end{array}$ & $\begin{array}{c}\mathrm{Fe}- \\
\text { calcareous } \\
\text { cement }\end{array}$ & $\begin{array}{l}\text { Replacement by cabo- } \\
\text { nates and smectite }\end{array}$ & $\begin{array}{l}\text { Clinoptilolite } \\
\text { analcime }\end{array}$ \\
\hline
\end{tabular}

Note: Data in the smectite columns are mean values calculated for all montmorillonites investigated. $\left(\mathrm{HWR}=\mathrm{height} / \mathrm{width}\right.$ ratio; $10-\AA$ index $\left(500^{\circ} \mathrm{C}\right)=10-\AA \mathrm{index}$ after heating to $\left.500^{\circ} \mathrm{C}\right) . \mathrm{Qz}=$ quartz; $\mathrm{IR}=$ wave number in $\mathrm{cm}^{-1}$ of infrared bands. There is an increase of dissolution pits in volcanic glass downsection.

Eocene $<2-\mu \mathrm{m}$ samples lack the typical bands that are attributed to kaolinite and show similarity with illite $\mathrm{O}-\mathrm{H}$ bands discussed by Farmer (1974). According to Stubican and Roy (1961), dioctahedral smectites show a distinct $\mathrm{H}-\mathrm{O}-\mathrm{Al}$ band, whereas this band is only poorly developed in dioctahedral micas (Stubican and Roy, 1961), The weak development of these bands in Oligocene and Eocene $<2-\mu \mathrm{m}$ samples also confirms the presence of mica-type structures in these smectites. It is noteworthy that the diagenesis of smectite is impeded in ash-rich layers, as indicated by a lower crystallinity of these smectites compared with smectites in the adjacent muds. This is consistent with the observation of a lack of zeolite formation in sediment with a very high glass content.

\section{SUMMARY}

The sediments drilled offshore Guatemala and Costa Rica are mainly composed of land-derived andesitic and rhyolitic detritus. The main components are intermediate plagioclase, quartz, amphiboles, volcanic rhyolitic glass, and detrital clay minerals. The hemipelagic part of the sediment is represented by opaline and calcitic tests. A special feature of the slope sediments off Guatemala are the ophiolitic rocks and their derived sediments.

As to diagenesis, only minor amounts of authigenic minerals as clinoptilolite, opal-CT, chalcedony, and carbonates are present; smectite is the prevalent authigenic mineral. A continuous transition from opal-A to chalcedony is observed in consolidated sediments of the Eocene. Dissolution pits on volcanic glass shards increase with sediment age. A neoformation of clinoptilolite and analcime was observed in Oligocene and Eocene sediments. The main clay mineral is a dioctahedral smectite that shows a clear increase of crystallinity with sediment age; in Eocene sediments it contains significant amounts of nonexpandable layers. Dolomite and argonite were found in serpentinitic muds. The dolomite occurrence in the normal sediment can presumably be related to the decay of organic matter. The trend of diagenesis in the slope sediments is shown in Table 6. The following general conclusions can be drawn: diagenesis in the slope sediments is controlled rather by time than by burial depth because of low temperature even in the lowermost sediments. Moreover, diagenesis seems to be impeded in pure ash layers. Thus diagenesis of silica minerals, glass, and zeolites is possibly controlled by the bulk composition of the sediment and is particularly sensitive to variation in calcareous and/or clayey admixtures.

\section{ACKNOWLEDGMENTS}

Prof. Dr. H. Füchtbauer deserves special acknowledgement for making my participation in Leg 84 possible, for extensive discussion of the final manuscript, and for his great assistance with preparation of the English text.

Further, I am particularly indebted to the scientific staff of the Departments of Geology and Mineralogy of the Ruhr-University, Bochum for their valuable criticism and support. In addition, I would like to thank Dr. Miriam Baltuck for critiquing the original manuscript. I also thank B. Kemper, U. Angermund, S. Krosse, A. Nolte, and P. Nolte, who offered a great deal of technical assistance. This investigation was supported by the Deutsche Forschungs-Gemeinschaft (project no. Fu 66/27).

\section{REFERENCES}

Alietti, A., 1972. Polymorphism and crystal-chemistry of heulandites and clinoptilolites. Am. Mineral., 57:1448-1462.

Aubouin, J., von Huene, R., Arnott, P. J., Baltuck, M., Bourgeois, J., Filewicz, M. V., Helm, R., Kvenvolden, K. A., Lienert, B., McDonald, T. J., McDougall, K., Ogawa, Y., Taylor, E., and Winsborough, B., 1982. Glomar Challenger operations, cruise summary, Leg 84, Middle America Trench. Joides J., 8(2):4-14.

Biscaye, P., 1965. Mineralogy and sedimentation of recent deep sea clay in the Atlantic Ocean and adjacent seas and oceans. Bull. Geol. Soc. Am., 76:803-832.

Boles, J. R., 1971. Synthesis of analcime from natural heulandite and clinoptilolite. Am. Mineral., 56:1724-1734.

1981. Zeolites in deep-sea sediments. In Mumpton, F. A. (Ed.), Mineralogy and Geology of Natural Zeolites. Reviews in Mineralogy, 6:137-163.

Boles, J. R., and Wise, W. S., 1978. Nature and origin of deep-sea clinoptilolite. In Sand, L. B., and Mumpton, F. A. (Eds.), Natural Zeolites, Occurrence, Properties, Use: New York (Pergamon Press), pp. 235-243. 
Brindley, G. W., and Brown, G., 1980. Crystal Structures of Clay Minerals and Their X-ray Identification: London (Mineralogical Society).

Buckner, D. A., Roy, D. M., and Roy, R., 1960. Studies in the system $\mathrm{CaO}-\mathrm{Al}_{2} \mathrm{O}_{3}-\mathrm{SiO}_{2}-\mathrm{H}_{2} \mathrm{O}$. Part 2, the system $\mathrm{CaSiO}_{3}-\mathrm{H}_{2} \mathrm{O}$. Am. J. Sci., 258:132-147.

Coleman, R. G., 1977. Ophiolites. Minerals and Rocks (Vol. 12): BerlinHeidelberg-New York, (Springer).

Cosgrove, M. E., and Papavassiliou, C. Th., 1979. Clinoptilolite in DSDP sediments of the Indian Ocean (Site 223, Leg 23): its stability conditions and estimation of its free energy. Mar. Geol., 33: M77-M84.

Davies, T. A., and Supko, P. R., 1973. Oceanic sediments and their diagenesis: some examples from Deep-Sea Drilling. J. Sediment. Petrol., 43(2):381-390.

Day, D. E., and Rindone, G. E., 1962. Properties of soda-aluminosilicate glasses. I. Refractive index, density, molar refractivity and infrared absorption spectra. J. Am. Ceram. Soc., 45:489-496.

Farmer, V. C., 1974. The layer silicates. The Infrared Spectra of Minerals: London (Mineralogical Society), pp. 331-363.

Goldsmith, J. R., and Graf, D. L., 1958. Structural and compositional variations in some natural dolomites. J. Geol., 66:678-693.

Goodyear, I., and Duffin, W. J., 1954. The identification and determination of feldspars by the X-ray powder method. Miner. Mag. 30: 306-321.

Harrison, W. E., Hesse, R., and Gieskes, J. M., 1982. Relationship between sedimentary facies and interstitial water chemistry of slope, Trench, and Cocos Plate sites from the Middle America Trench transect, active margin off Guatemala, DSDP Leg 67. In Aubouin, J., von Huene, R., et al. Init. Repts. DSDP, 67: Washington (U.S. Govt. Printing Office), 603-614.

Heinemann, C., and Füchtbauer, H., 1982. Insoluble residues of the fine-grained sediments from the Trench transect south of Guatemala, DSDP Leg 67. In Aubouin, J., von Huene, R. et al., Init. Repts. DSDP, 67: Washington (U.S. Govt. Printing Office), 497-506.

Helgeson, H. C., Garrels, R. M., and Mackenzie, F. T., 1969. Evaluation of irreversible reactions in geochemical processes involving minerals and aqueous solutions. II. Applications. Geochim. Cosmochim. Acta, 33:455-481.

Hoffman, J., and Hower, J., 1979. Clay mineral assemblages as lowgrade metamorphic geothermometers: application to the thrust faulted disturbed belt of Montana, U.S.A. Spec. Publ. Soc. Econ. Paleontol. Mineral., 26: 55-79.

Honnorez, J., and Kirst, P., 1975. Petrology of rodingites from the Equatorial Mid-Atlantic fracture zones and their geotectonic significance. Contrib. Mineral. Petrol., 49:233-257.

Hurd, D. C., and Theyer, F., 1975. Changes in the physical and chemical properties of biogenic silica from the Central Equatorial Pacific. I. Solubility, specific surface area, and solution rate constants of acid-cleaned samples. Adv. Chem. Ser., 147:211-230.

Kastner, M., 1983. Origin of dolomite and its spatial and chronological distribution-a new insight. Am. Assoc. Pet. Geol. Bull., 67(11): 2156.

Kastner, M., Keene, J. B., and Gieskes, J. M., 1977. Diagenesis of siliceous oozes. I. chemical controls on the rate of opal-A to opal-CT transformation - an experimental study. Geochim. Cosmochim. Acta, 41:1041-1059.

Kelts, K., and McKenzie, J. A., 1982. Diagenetic dolomite formation in quaternary anoxic diatomaceous muds of DSDP Leg 64, Gulf of California. In Curray, J. R., Moore, D. G., et al., Init. Repts. DSDP, 64: Washington (U.S. Govt. Printing Office), 595-609.

Kurnosov, V., Murdmaa, J. Kazakova, V., Mikhina, V., and Shevchenko, A., 1982. Mineralogy of sediments from the Middle America Trench. In Aubouin, J., von Huene, R., et al., Init. Repts. DSDP, 67: Washington (U.S. Govt. Printing Office), 515-528.
Lippmann, F., 1973. Sedimentary Carbonate Minerals. Minerals and Rocks (Vol. 6): Berlin-Heidelberg-New York (Springer).

Mackenzie, R. C., 1957. The Differential Thermal Investigation of Clays: London (Mineralogical Society).

Manheim, F. T., and Gulbrandsen, R. A., 1979. Marine phosphorites. In Burns, R. G. (Ed.), Marine Minerals. Reviews in Mineralogy, 6: 151-170.

Mariner, R. H., and Surdam, R. C., 1970. Alkalinity and formation of zeolites in saline-alkaline lakes. Science, 170:977-979.

Müller, G., 1964. Sediment-Petrologie, I: Methoden der Sediment Untersuchung: Stuttgart (Schweizerbart).

Pearce, J. A., and Cann, J. R., 1973. Ophiolite origin investigated by discriminant analysis using $\mathrm{Ti}, \mathrm{Zr}$, and Y. Earth Planet. Sci. Lett., $12: 339-439$.

Piller, H., 1952. Die Phasenkontrastmikroskopie als Hilfsmittel zur Bestimmung feinkörniger, speziell dünner, transparenter Minerale. Heidelb. Beitr. Mineral. Petrogr., 3:307-334.

Pisciotto, K. A., and Mahoney, J. J., 1981. Isotopic survey of diagenetic carbonates, DSDP Leg 63: In Yeats, R. S., Haq, B. U., et al., Init. Repts. DSDP, 63: Washington (U.S. Govt. Printing Office), 595-609.

Prasad, S., and Hesse, R., 1982. Provenance of detrital sediments from the Middle America Trench transect off Guatemala, DSDP Leg 84. In Aubouin, J., von Huene, R., et al., Init. Repts. DSDP, 67: Washington (U.S. Govt. Printing Office), 507-514.

Reynolds, R. C., and Hower, J., 1970. The nature of interlayering in mixed layer illite-montmorillonite. Clays Clay Miner., 18:25-36.

Riech, V., and von Rad, U., 1979. Silica diagenesis in the Atlantic Ocean: diagenetic potential and transformations. Am. Geophys. Union, 3:325-340.

Schlanger, S. O., and Douglas, R. G., 1974. The pelagic ooze-chalklimestone transition and its implication for marine stratigraphy. In Hsü, K. J., and Jenkyns, H. C. (Eds.), Pelagic Sediments: On Land and Under The Sea. Spec. Publ. Int. Assoc. Sedimentol., 1: 117-148.

Schmincke, H. -U., 1982. Ash from vitric muds in deep sea cores from the Mariana trough and fore-arc region (South Phillipine Sea) (Sites $453,454,455,458,459$, SP). In Hussong, D., Uyeda, S., et al., Init. Repts. DSDP, 60: Washington (U.S. Govt. Printing Office), 473-481.

Shepard, F. P., 1954. Nomenclature based on sand-silt-clay ratios. J. Sediment. Petrol., 24:151.

Stolper, E., 1982. Water in silicate glasses: an infrared spectroscopic study. Contrib. Mineral. Petrol. 81:1-17.

Stubican, V., and Roy, R., 1961. Isomorphous substitution and infrared spectra of the layer lattice silicates. Am, Mineral. 46:32-51.

Thorez, J., 1975. Phyllosilicates and Clay Minerals. A Laboratory Handbook for Their X-ray Diffraction Analyses: Dison, Belgium (Lelotte).

Truesdell, A. H., and Jones, B. F., 1973. WATEQ, a computer program for calculating chemical equilibria on natural waters. Nat. Tech. Info. Serv., P.B. 220464.

von Huene, R., and Aubouin, J., 1982. Summary - Leg 67, Middle America Trench transect off Guatemala. In Aubouin, J., von Huene, R., et al., Init. Repts. DSDP, 67: Washington (U.S. Govt. Printing Office), 775-792.

Wolff, M., and Füchtbauer, H., 1976. Die karbonatische Randfazies der tertiären Süßwasserseen des Nördlinger Ries und des Steinheimer Beckens. Geol. Jahrb., D14:3-53.

Date of Initial Receipt: 9 January 1984 Date of Acceptance: 29 March 1984 

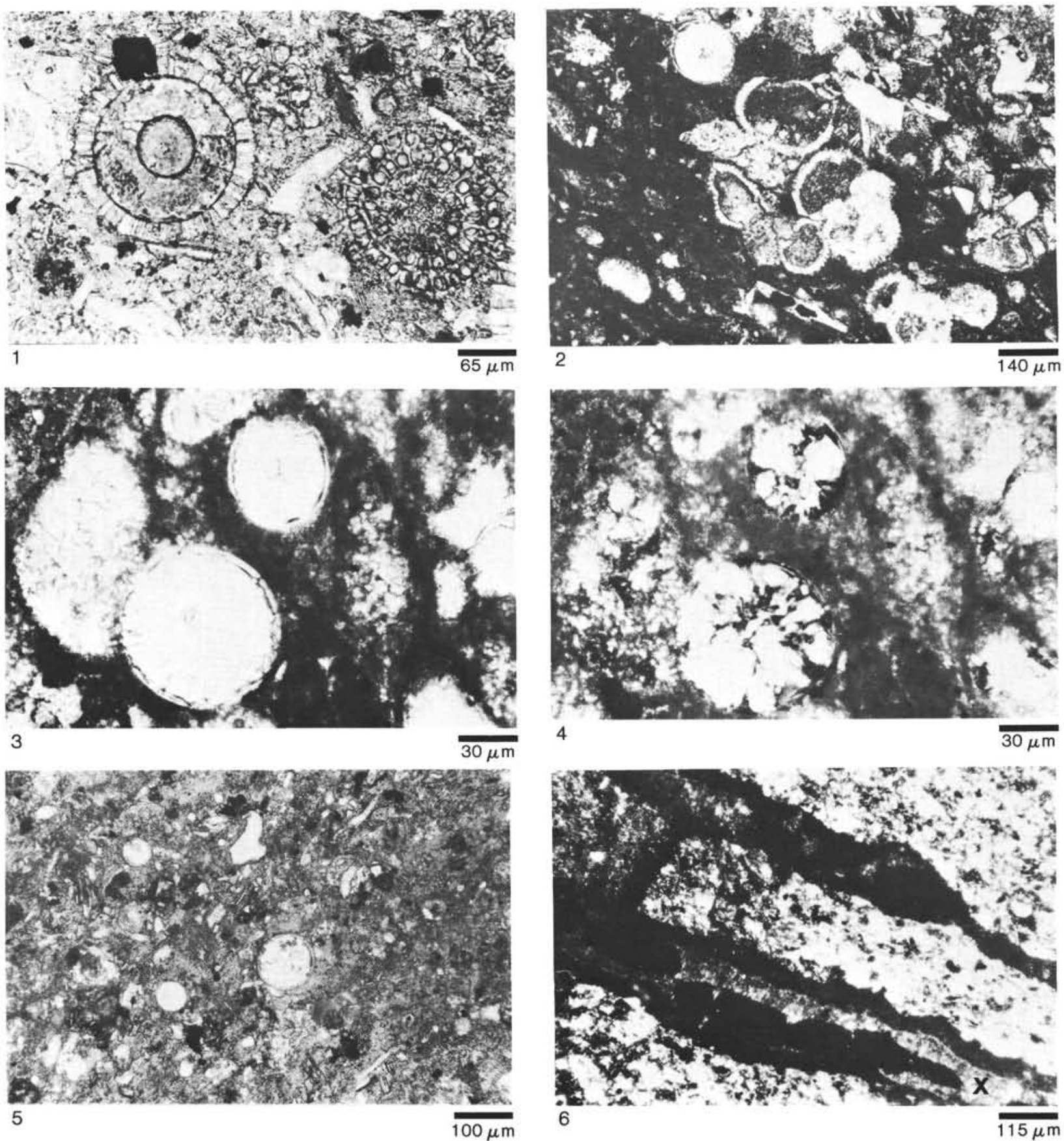

Plate 1. 1. Radiolarian skeleton in Sample $570-37-1,15-20 \mathrm{~cm}$. Opal-A tests in early Eocene clayey sediment. 2. Foraminifer and radiolarian tests, which are dissolved or replaced by calcite and chalcedony, consolidated limestone, Sample 570-38-1, 50-52 cm, early Eocene. 3. Radiolarian tests replaced by calcite and chalcedony, Sample 570-38-1, 50-52 cm, early Eocene. 4. Same as Figure 3, with crossed nicols, Sample 570-38$1,50-52 \mathrm{~cm}$, early Eocene. 5. Radiolarian tests in the sedimentary cover of the serpentinite basement of Site 570 are replaced by chalcedony, Sample 570-39, CC (6-9 cm), early Eocene. 6. Same sample as Figure 5, but showing fissure fills of clinoptilolite, gyrolite, and analcime (analcime is isotropic, clinoptilolite shows very low, and gyrolite [x], higher, birefringence). 

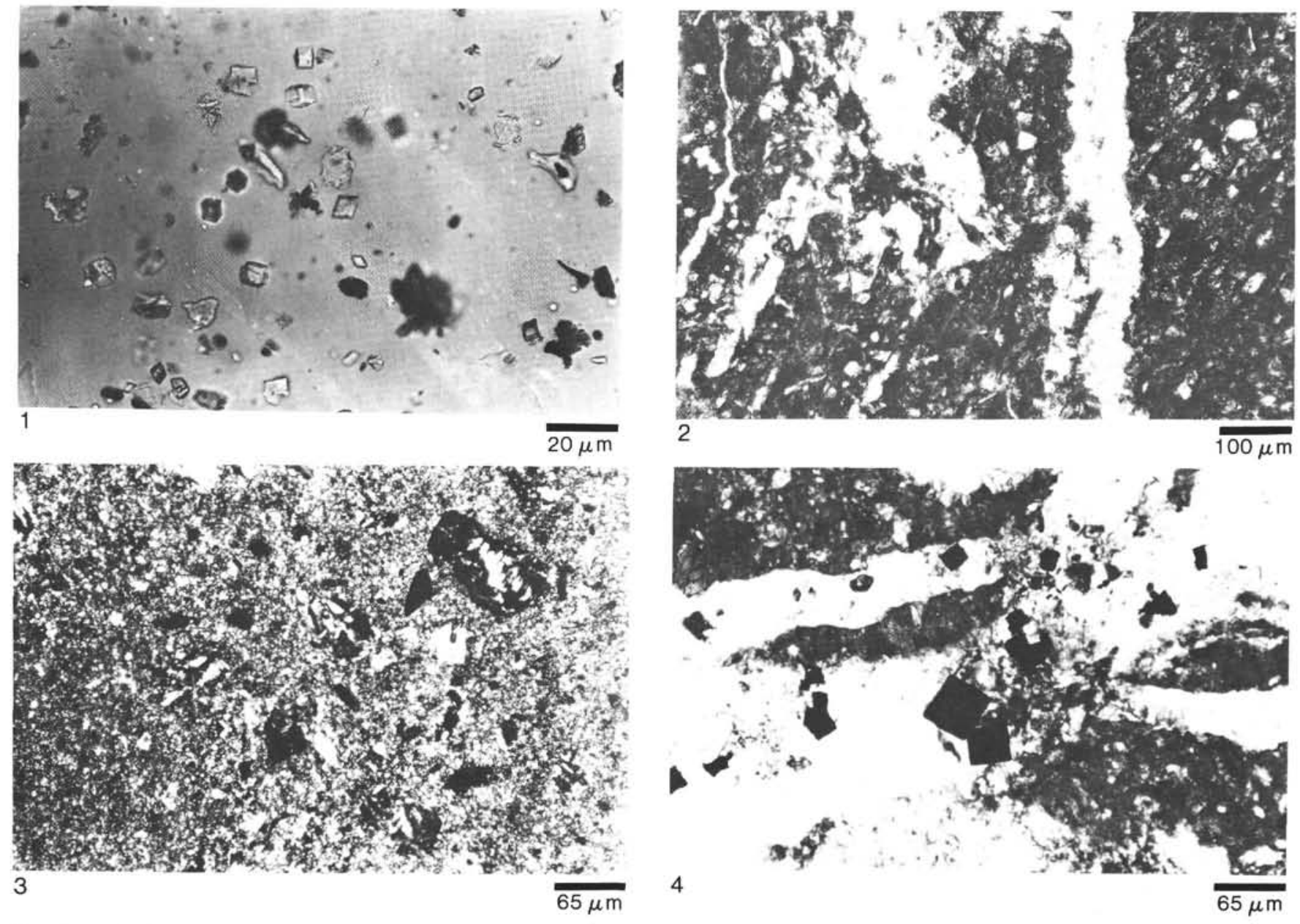

Plate 2. 1. Isolated dolomite rhombs in Sample 570-19-2, 76-78 cm, Pleistocene. 2. Clinoptilolite filling fissures and replacing the clayey groundmass, (570-39-1, 115-117 cm, early Eocene). 3. Dolomite-cemented serpentinite detritus, Sample 566-5-3, 83-85 cm, crossed polars. 4. Cubic pyrite crystals, Sample 570-39-1, 115-117 cm, early Eocene. 


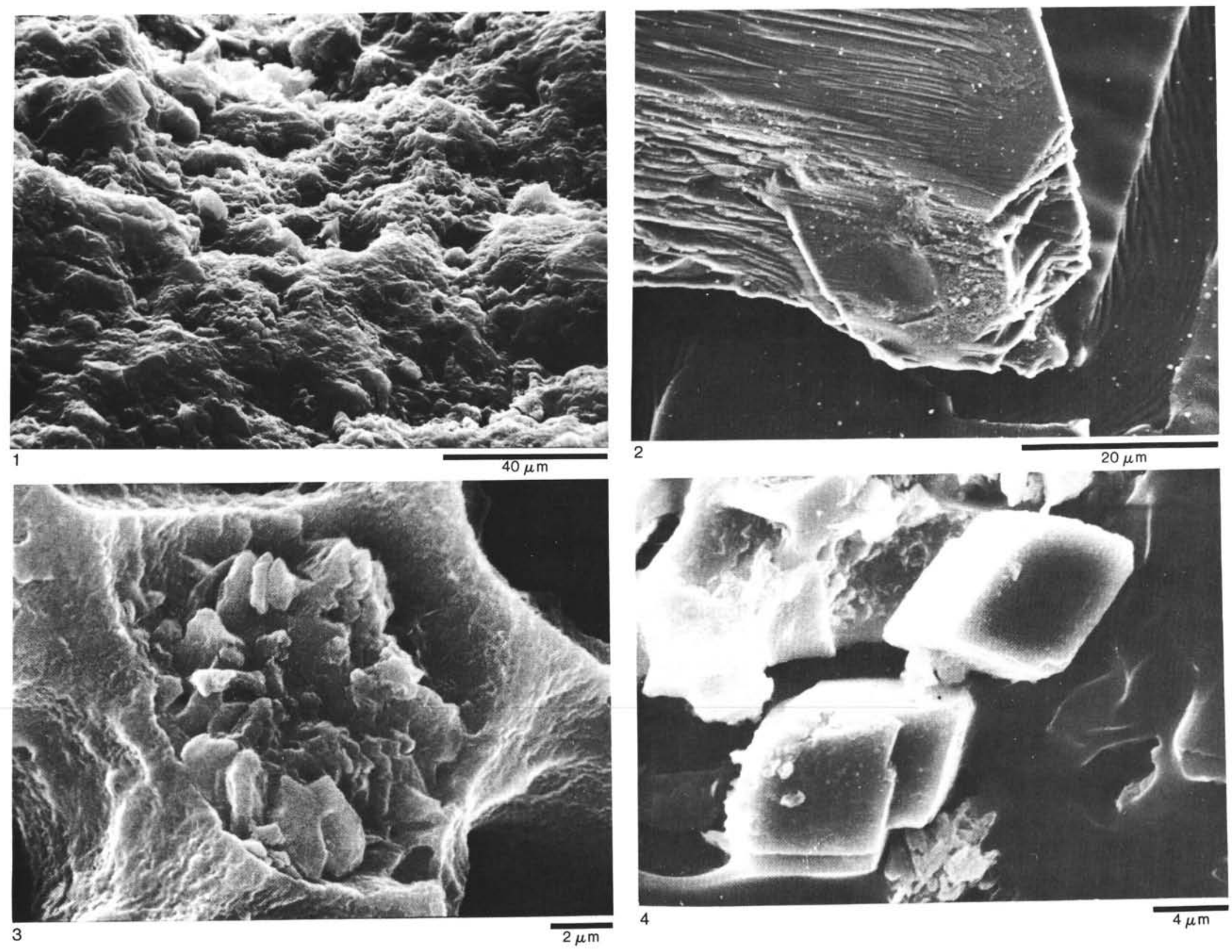

Plate 3. 1. Clay-filled vein in Sample 569-26-2, 50-52 cm. Texture suggests accretion of clay plates. 2. Plagioclase grain without etching pits, Sample 568-41-4, 70-72 cm, Miocene. 3. Etched radiolarian tests with mineral fillings, presumably smectite, according to shape and chemical composition (EDAX), Sample 569A-9-2, 0-2 cm, late Eocene. 4 . Isolated dolomite crystals in Sample 570-19-2, 76-78 cm, Pleistocene. 


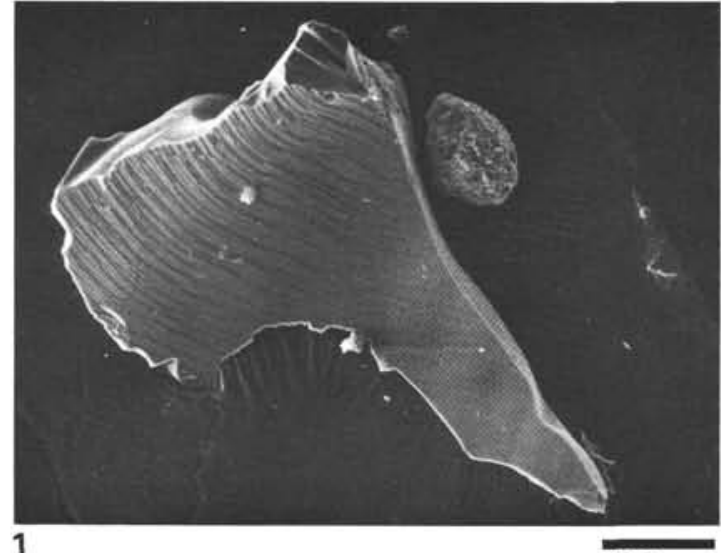

1

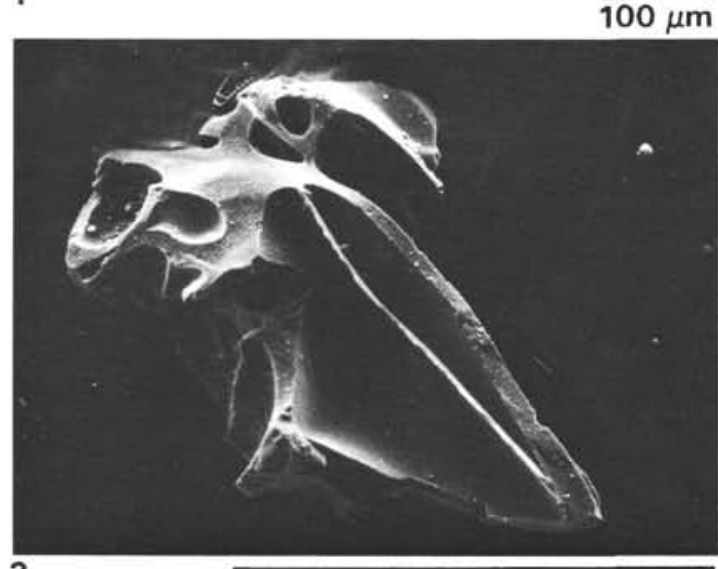

3

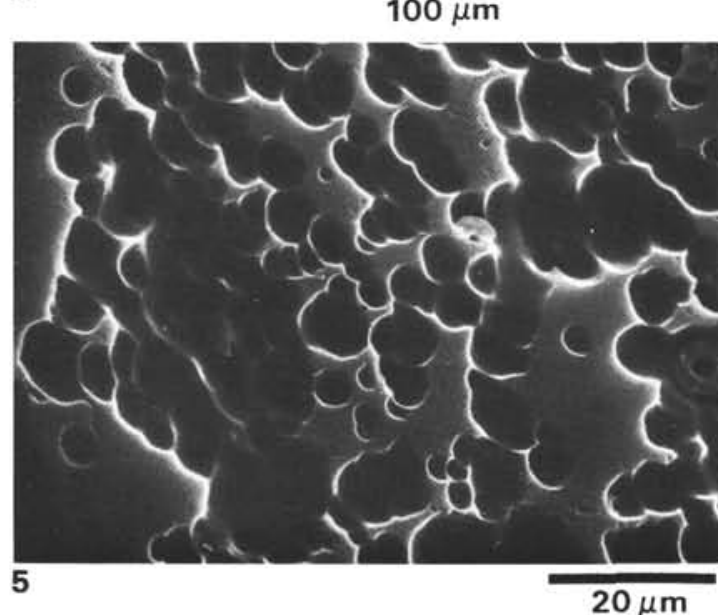

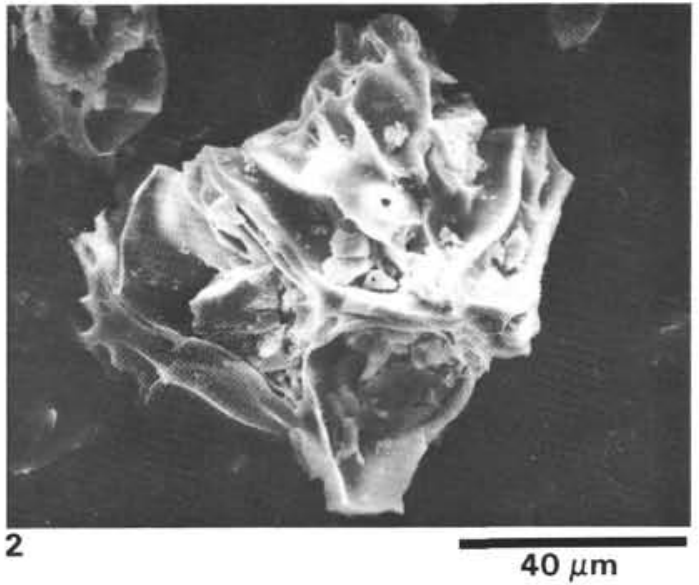
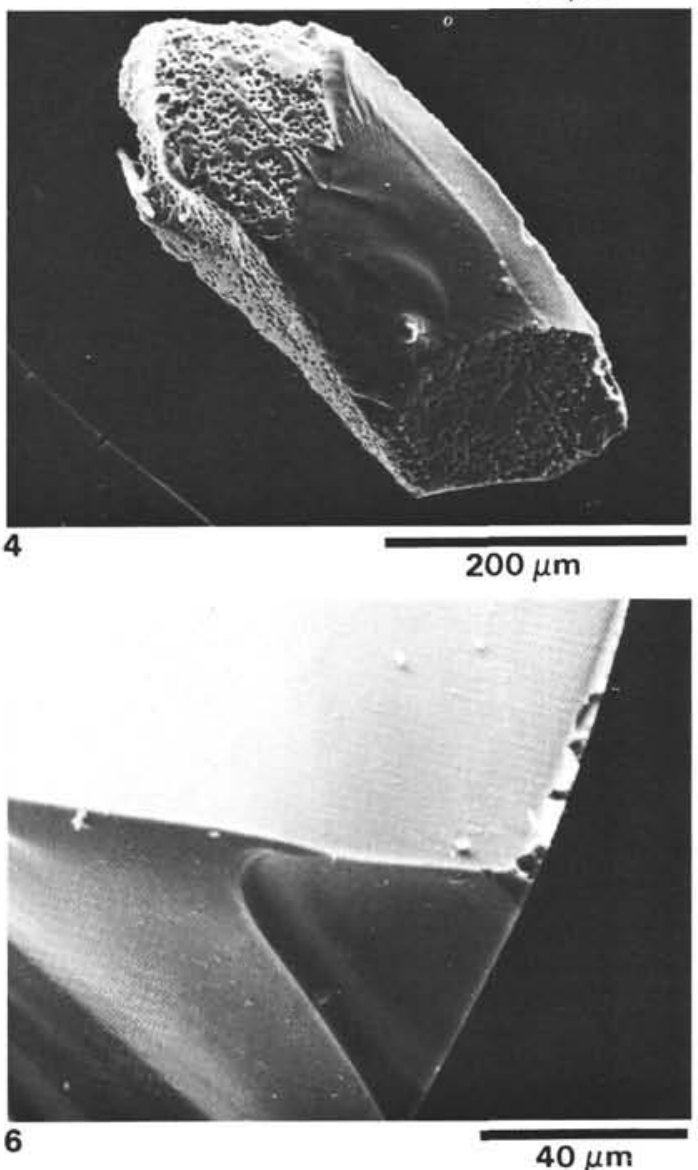

Plate 4. 1. Tubular pumice, the main shard type in the ash layers investigated, Sample $568-41-4,70-72 \mathrm{~cm}$, early Miocene. 2. Shard consisting mainly of bubble junction walls. This type is second in abundance, Sample 569-3,CC. 3. Shard type with elongated large bubbles. This is the rarest shard type, Sample 568-12-5, 102-104 cm, Pleistocene. 4. Glass shard of a late Eocene sediment. The surface is covered with dissolution pits, Sample 569A-9-2, 0-2 cm. 5. Enlargement of a shard surface region with a lot of dissolution pits, Sample 569A-9-2, 0-2 cm, late Eocene, $333 \mathrm{~m}$ sub-bottom depth. 6. Very slight etching of edges of a Pleistocene glass Sample 569-3,CC (54-56 cm), $20 \mathrm{~m}$ sub-bottom depth. 